medRxiv preprint doi: https://doi.org/10.1101/2022.01.13.22269204; this version posted January 13, 2022. The copyright holder for this preprint

(which was not certified by peer review) is the author/funder, who has granted medRxiv a license to display the preprint in perpetuity.

All rights reserved. No reuse allowed without permission.

\title{
Metabolic and proteomic signatures of type 2 diabetes subtypes in an Arab population
}

Shaza B. Zaghlool ${ }^{1}$, Anna Halama ${ }^{1}$, Nisha Stephan ${ }^{1}$, Manonanthini Thangam² ${ }^{2}$ Emma Ahlqvist ${ }^{2}$, Omar M. E. Albagha ${ }^{3,4}$, Abdul Badi Abou?Samra ${ }^{5}$, Karsten Suhre ${ }^{1}$

${ }^{1}$ Department of Physiology and Biophysics, Weill Cornell Medicine-Qatar, Doha, Qatar.

${ }^{2}$ Department of Clinical Sciences Malmö, Lund University, Sweden.

${ }^{3}$ College of Health and Life Sciences, Hamad Bin Khalifa University, Education City, Doha, Qatar.

${ }^{4}$ Centre for Genomic and Experimental Medicine, Institute of Genetics and Cancer, University of Edinburgh, Edinburgh, UK.

${ }^{5}$ Qatar Metabolic Institute, Hamad Medical Corporation, Doha, Qatar.

Correspondence to K.S.: kas2049@qatar-med.cornell.edu 
medRxiv preprint doi: https://doi.org/10.1101/2022.01.13.22269204; this version posted January 13, 2022. The copyright holder for this preprint (which was not certified by peer review) is the author/funder, who has granted medRxiv a license to display the preprint in perpetuity.

All rights reserved. No reuse allowed without permission.

\begin{abstract}
Background. Type 2 diabetes (T2D) has a heterogeneous etiology which is increasingly recognized to influence the risk of complications and choice of treatment. A data driven cluster analysis in four separate European populations of patients with type 2 diabetes identified four subtypes of severe insulin dependent (SIDD), severe insulin resistant (SIRD), mild obesityrelated (MOD), and mild age-related (MARD) (Ahlqvist et al., Lancet Diabetes Endocrinology, 2018). Our aim was to extend this classification to the Arab population of Qatar and characterize the biological processes that differentiate these subtypes in relation to metabolomic and proteomic signatures.
\end{abstract}

Methods. The Ahlqvist et al. subtype clustering approach was applied to 631 individuals with T2D from the Qatar Biobank (QBB) and validated in an independent set of 420 participants from the same population. The association between blood metabolites $(n=1,159)$ and protein levels $(n=1,305)$ with each cluster were established.

Findings. The four subtypes of T2D were reproduced and validated in the population of Qatar. Cluster-specific metabolomic and proteomic associations revealed subtype-specific molecular processes. Activation of the complement system with many features of autoimmune diabetes and reduced 1,5-anhydroglucitol (1,5-AG) characterized SIDD, with evidence of impaired insulin signaling in SIRD, elevated leptin and fatty acid binding protein in MOD, whilst MARD appeared to be the healthiest subgroup.

Interpretation. We have replicated the four T2D clusters in an Arab population and identified distinct metabolic and proteomic signatures, providing insights into underlying etiology with the potential to deploy subtype-specific treatment options.

Keywords: type 2 diabetes, diabetes subtypes, proteomics, metabolomics, non-European populations 
medRxiv preprint doi: https://doi.org/10.1101/2022.01.13.22269204; this version posted January 13, 2022. The copyright holder for this preprint (which was not certified by peer review) is the author/funder, who has granted medRxiv a license to display the preprint in perpetuity.

All rights reserved. No reuse allowed without permission.

\section{INTRODUCTION}

Type 2 diabetes (T2D) is a complex metabolic disorder defined by dysregulated glucose homeostasis, driven by imbalanced energy intake and expenditure, dysfunction of insulin signaling and chronic inflammation ${ }^{1-3}$. Multiple therapies are now available to improve glycemic control ${ }^{4}$ and provide additional benefits in relation to complications ${ }^{5-7}$. Indeed, individualized therapies targeting the underlying pathophysiology and complications should be a major goal in the treatment of patients with $T 2 D^{1}$.

Ahlqvist et al. ${ }^{8}$ used data on age at diagnosis, $\mathrm{BMI}, \mathrm{HbA}_{1 \mathrm{c}}$, homeostasis model assessment (HOMA) estimates of $\beta$-cell function (HOMA2-B), insulin resistance (HOMA2-IR), and presence or absence of glutamic acid decarboxylase antibodies (GADA) to stratify subjects into four clusters representing T2D subtypes and one cluster with severe autoimmune diabetes (SAID) ${ }^{8}$. The four T2D clusters were named in reference to their characterizing phenotypic signatures as Severe Insulin Dependent Diabetes (SIDD), Severe Insulin Resistant Diabetes (SIRD), Mild Obesity-related Diabetes (MOD) and Mild Age-related Diabetes (MARD). Since its publication in 2018, the paper has been cited over 600 times and discussed in multiple reviews ${ }^{1,9-13}$. The clusters have been replicated in British ${ }^{14}$, German ${ }^{15,16}$, Mexican American and Chinese ${ }^{17-19}$, Japanese ${ }^{20}$, Asian Indian ${ }^{21}$, Mexican ${ }^{22}$ and Icelandic ${ }^{23}$ cohorts, suggesting a generalizability to other ethnicities. In the original analysis predisposition to retinopathy and nephropathy were identified in different clusters, and more recently a German cohort cluster analysis has revealed predisposition to non-alcoholic fatty liver disease and diabetic neuropathy ${ }^{15}$. A study clustering genetic risk loci for T2D associated traits observed some overlap with the clusters of Ahlqvist ${ }^{24}$. More recently, evidence for distinct genetic backgrounds of the subtypes has been found ${ }^{25}$. Schüssler-Fiorenza Rose et al. ${ }^{26}$ used multi-omics measurements in a longitudinal study to develop prediction models for insulin resistance and the German Diabetes Study (GDS) showed differences in protein biomarkers of inflammation between subgroups ${ }^{16}$. These studies suggest that deep molecular phenotyping may provide key insights into the underlying pathophysiology of glucose dysregulation and development and progression of comorbidities in patients with T2D. 
Whilst a mechanistic link has been suggested between increased fat storage and compromised glucose homeostasis ${ }^{27}$, body mass index (BMI) alone does not explain the difference between normal and dysfunctional glucose metabolism. Specific metabolic and proteomic processes may help to characterize the broader spectrum of physiological perturbations associated with impaired glucose metabolism to enable subtype-specific individualization of therapies. We hypothesized that there are distinctive alterations in metabolic and proteomic components of signaling pathways underlying the different T2D clusters.

We have analyzed data from the Qatar Biobank (QBB) population and translated the Ahlqvist et al. clustering approach to an Arab population. Further, applying broad non-targeted metabolomics and affinity proteomics profiling we have identified cluster specific physiological and biochemical processes in relation to their predominant treatment regimens (Figure 1).

\section{METHODS}

Study population. Qatar Biobank (QBB) includes a population of Qatar nationals or long-term residents ( $\geq 15$ years living in Qatar), aged 18 years and older in the State of Qatar ${ }^{28}$. Extensive baseline socio-demographic data, clinical and behavioral phenotypic data and serum concentrations of $\mathrm{HbA}_{1 c}$, triglycerides, glucose, C-peptide, creatinine, total cholesterol, LDL-C and HDL-C, and multiple other clinical biochemistry parameters ${ }^{29}$ have been measured at the central laboratory of Hamad Medical Corporation (HMC), accredited by the College of American Pathologists.

All QBB participants signed an informed consent form prior to their participation. The study was approved by HMC ethics committee and the QBB institutional review board. At the time of analysis, QBB data was available for 6,218 participants. Over $96 \%$ of the participants reported having grandparents that were Qatari nationals. For 2,155 individuals, metabolomics and proteomics data had been collected in parallel. 429 participants with incomplete records and 
medRxiv preprint doi: https://doi.org/10.1101/2022.01.13.22269204; this version posted January 13, 2022. The copyright holder for this preprint (which was not certified by peer review) is the author/funder, who has granted medRxiv a license to display the preprint in perpetuity.

All rights reserved. No reuse allowed without permission.

894 individuals with $\mathrm{HbA}_{1 c}$ ranging between 5.7 and 6.4 who did not match our diabetes definition (see below) were excluded, leaving 4,895 samples for analysis. Blood samples were collected more than 2 hours after their last meal or calorie-containing drink in $77 \%$ of participants. $50.7 \%$ of the participants $(52.8 \%$ of the T2D cases and $40.6 \%$ of the controls) had been fasting for over 8 hours. This dataset was split into two groups, using the samples without omics data as a training set for the clustering $(\mathrm{N}=2,740)$, and the samples with omics data as a testing set for validation, and to further evaluate the associations of the metabolite and protein levels with T2D in a case-control setting and with T2D subtypes $(N=2,155)$.

The group without omics data contained 631 individuals with T2D which were used to define the cluster coordinates. The group with omics data contained 420 individuals with T2D and was used for cluster validation, and then further for metabolomics and proteomics associations analyses (Figure 1). The study demographics for the two groups together are shown in Table 1. Both groups of data were similar, ie. clinical variables had comparable mean values and percentages in both the T2D cases and controls (Supplementary Table 1).

Definition of T2D and controls. Subjects were defined as controls if all the following four conditions were met: first, no self-reported physician diagnosis of diabetes; second, no selfreported treatment with any diabetes specific medication; third, $\mathrm{HbA}_{1 \mathrm{c}}<5.7 \%$; and fourth, random glucose level $<200 \mathrm{mg} / \mathrm{dL}$. T2D was defined if any one of the following four conditions was met: first, having a physician diagnosis of diabetes based on the questionnaire $(13.3 \%$ of all participants), second, being under diabetes treatment based on the QBB questionnaire (11.6\%), third, having an $\mathrm{HbA}_{1 \mathrm{c}}>6.5 \%$ (10.5\%), or fourth, having a random glucose level $>200 \mathrm{mg} / \mathrm{dL}$ (3.3\%). Based on this definition, $15.4 \%$ of individuals were defined as T2D cases. Most individuals with a physician diagnosis of diabetes were on oral anti-diabetic treatment (73.7\%), insulin treatment (23.9\%), diet treatment (38.3\%) and/or physical activity treatment (16.2\%) (see Supplementary Figure 1 for a Venn diagram). Individuals with $\mathrm{HbA}_{1 c}$ between $5.7 \%$ and $6.4 \%(N=894)$ or self-reported gestational diabetes $(\mathrm{N}=4)$ were excluded. Ahlqvist et al. used glutamic acid decarboxylase antibodies (GADA) to define an additional subtype of severe 
medRxiv preprint doi: https://doi.org/10.1101/2022.01.13.22269204; this version posted January 13, 2022. The copyright holder for this preprint (which was not certified by peer review) is the author/funder, who has granted medRxiv a license to display the preprint in perpetuity.

All rights reserved. No reuse allowed without permission.

autoimmune diabetes (SAID). As GADA measurements were not available in QBB, individuals with self-reported type 1 diabetes (T1D) or C-peptide concentrations below $0.5 \mathrm{nmol} / \mathrm{L}$ and on insulin treatment were classified as SAID ( $N=109)$. These individuals were excluded from the statistical analysis, but the proteomic and metabolic levels of this subgroup are shown where appropriate.

Training and testing sets. The cohort was split into two sets, a training set $(\mathrm{N}=2,740)$ and a testing set $(\mathrm{N}=2,155)$. The latter was chosen to overlap with available proteomics, metabolomics, and medication usage data. There were no substantial differences in demographics between the training and the testing set (Supplementary Table 1). The training set included 631 individuals with T2D, and the testing set included 420 individuals with T2D.

Medication. QBB study participants provided information on their regular usage of over the counter and prescription medication as free text, which required annotation and homogenization. The questionnaire included the following question: "Are you taking any overthe-counter medication or prescription medicines regularly? For example, daily, weekly, monthly or every few months - such as depot injections?" and allowed participants to provide up to 30 free text entries. Anatomical Therapeutic Chemical (ATC) ${ }^{30}$ annotation was retrieved from the DrugBank annotation file. We annotated all entries from the questionnaire with a unique active molecule from the DrugBank repository, molecular class, indication, and its corresponding ATC code where available. The medication data covered 394 unique molecules, 529 ATC codes, 218 molecular classes, and 117 indications.

Proteomics. Levels of 1,305 blood circulating proteins (Supplementary Table 2) were measured for 2,935 samples using the aptamer-based SOMAscan platform (kit version 1.3, Somalogic, Boulder, CO) ${ }^{31}$ implemented at Weill Cornell Medicine - Qatar, as previously described ${ }^{32}$. A detailed description of the platform can be found in the "SOMAmer Reagent Specificity Technical White Paper SM-500-102015", which was originally available on Somalogic's web-site http://info.somalogic.com/hubfs/January_2016/SSM-002-Rev-3-SOMAscan-Technical-White- 
medRxiv preprint doi: https://doi.org/10.1101/2022.01.13.22269204; this version posted January 13, 2022. The copyright holder for this preprint (which was not certified by peer review) is the author/funder, who has granted medRxiv a license to display the preprint in perpetuity.

All rights reserved. No reuse allowed without permission.

Paper.pdf (accessed November 26, 2016) and is now archived and available at https://studyres.com/doc/7837606/technical-white-paper. Briefly, EDTA-plasma was incubated with bead-coupled epitope-specific aptamers (SOMAmers). Bead-bound proteins were then biotinylated and complexes comprising biotinylated target proteins and fluorescence-labelled SOMAmers were photocleaved and recaptured on streptavidin beads. SOMAmers were then eluted and quantified by hybridization to custom arrays of SOMAmer-complementary oligonucleotides. The resulting raw intensities were processed using different standards as a reference, including hybridization normalization, median signal normalization and signal calibration to control for inter-plate differences. No samples or data points were excluded. Overlapping phenotype data was obtained for 2,155 of the 2,935 samples and proteomics data for these samples were used. Quality control was performed using repeated measures of two QC samples. The median coefficient of variance (CV) was 0.073 for both QC samples, based on 51 and 54 repeated measures, respectively. 95\% of the aptamers had a CV below 0.172 and 0.176 , respectively, and $5 \%$ had a CV below 0.046 and 0.041 , respectively.

Metabolomics. 1,159 metabolites (937 named compounds and 222 compounds of unknown structural identity) were quantified using Metabolon HD4 technology (Metabolon Inc., Durham, NC) (Supplementary Table 3) for 3,000 samples as previously described ${ }^{33,34}$. All measurements were performed on a Metabolon HD4 platform implemented at the Anti-Doping Laboratory in Qatar (ADLQ) under a joint laboratory agreement with Metabolon and support from Weill Cornell Medicine - Qatar, the Qatar Biomedical Research Institute, and the interim Translational Research Institute (iTRI) of HMC. For 2,155 of the 3,000 samples, we obtained overlapping phenotype data for this study. Metabolomics data for these samples were used. Instrument variability, based on measurement of internal standards, was $12 \%$ and total process variability, based on endogenous biochemicals measured in repeated reference samples, was $16 \%$.

Statistical analysis. Statistical analysis was conducted using R (version 4.0.5) and RStudio (version 1.4.1106). T-tests, Fisher exact tests, and linear and logistic regression models with covariates as indicated were conducted as appropriate based on the respective variable types, using subroutines implemented in base R. Multiple testing was accounted for using 
medRxiv preprint doi: https://doi.org/10.1101/2022.01.13.22269204; this version posted January 13, 2022. The copyright holder for this preprint (which was not certified by peer review) is the author/funder, who has granted medRxiv a license to display the preprint in perpetuity.

All rights reserved. No reuse allowed without permission.

conservative Bonferroni correction at a significance level of 0.05 divided by the number of tests conducted in the specific cases (number of metabolites, proteins, traits taken forward for replication, etc. as indicated).

Cluster Analysis. Model parameters were selected based on five commonly measured variables as in Ahlqvist et al. ${ }^{8}$. We used BMI, age at onset of diabetes, and homeostasis model assessment HOMA2 estimates of ß-cell function (HOMA2-B) and insulin resistance (HOMA2-IR) based on C-peptide concentrations calculated with the HOMA calculator (University of Oxford, Oxford, UK) ${ }^{35}$. Patients defined as SAID (see above) were excluded from the clustering and assigned to their own subtype, and clustering was carried out on the T2D patients only. Cluster analysis was carried out on standardized values centered to mean=0 and s.d.=1. The optimal number of clusters was determined from the training set using the Mclust function in the "mclust" R library v.5.4.5. Clusters coordinates were identified in the training set of QBB individuals ( $N=631$ ) and applied to a separate QBB set which was deeply phenotyped ( $N=420)$. We determined the optimal number of clusters using the Bayesian Information Criterion (BIC) for expectation-maximization, initialized by hierarchical clustering for parameterized Gaussian mixture models. We computed the BIC for various cluster sizes (two to 15). Using $k$-means cluster analysis on standardized variables, we derived cluster center coordinates for different values of $k$ (Supplementary Figure 2). Using a voting scheme ${ }^{36}$, we determined the optimal number of clusters to be $k=4$ (Supplementary Figure 3 ). This finding was consistent with that observed by Ahlqvist et al. Cluster stability was assessed by Jaccard similarity ${ }^{37}$ using 2000 reruns of the $k$-means procedure. The Jaccard similarity to the original clusters was greater than 0.75 , which is generally considered an acceptable threshold for cluster stability ${ }^{37}$. The cluster variables in QBB followed a similar trend to ANDIS. We therefore assigned cluster labels based on the variable averages that were characteristic of each T2D subtype following Ahlqvist et al.

Robustness and reproducibility analysis. To ensure robustness and reproducibility of our results, we undertook a number of sensitivity tests on the cluster analysis. First, we replicated the clustering in the testing set and compared that to using cluster coordinates from the training set. In the case of clustering in the testing set, the assigned clusters from the k-means algorithm were used directly. However, when using the training set coordinates, cluster 
medRxiv preprint doi: https://doi.org/10.1101/2022.01.13.22269204; this version posted January 13, 2022. The copyright holder for this preprint (which was not certified by peer review) is the author/funder, who has granted medRxiv a license to display the preprint in perpetuity.

All rights reserved. No reuse allowed without permission.

membership was determined by assigning every individual in the testing set to the cluster with the minimum Euclidean distance to the training coordinates. We then repeated the clustering with varying numbers of clusters. We also repeated the cluster analysis separately for females and males. As QBB participants were not all in a fully fasting state, we further tested the sensitivity of the cluster assignments to self-reported time-since-last-meal. Finally, we tested whether ANDIS cluster centers could be used directly to classify QBB participants into T2D subtype clusters.

Identification of T2D-associated proteins and metabolites. For proteins, logistic regression models $(\mathrm{glm})$ were used to test for association with the T2D state, including age, sex, and technical covariates into the model. Technical covariates include log(HSP90) which is a measure of cell lysis, week of sample collection, fasting minutes, and SomaLogic tube number. For metabolites, linear regression models $(\mathrm{Im})$ were used to test for association with T2D using age, sex, BMI, and technical covariates into the model. Different types of models (glm for proteins and Im for metabolites) were used for consistency with previously published work ${ }^{23,38}$. Protein and metabolite levels were log-scaled, z-scored, and outliers were winsorized to 5 s.d. before computing the association.

Replication of association of T2D with proteomics. Association data for the replication of the T2D protein association was obtained from the published AGES study ${ }^{23}$. In that study, serum levels of 4,137 proteins, targeted by 4,782 SOMAmers, were measured at SomaLogic (Boulder, CO) in samples from 5,457 AGES-Reykjavik participants, as previously described ${ }^{39}$. The AGESReykjavik cohort included 654 individuals with T2D and 4,784 controls. After applying a Box-Cox transformation on the protein data, associations between serum protein levels and prevalent or incident type 2 diabetes were determined using a logistic regression adjusted for age and sex. After following the same preprocessing steps and statistical methods, we replicated the associations for proteins that were shared between QBB and AGES ( $N=107)$.

Replication of association of T2D with metabolomics. Metabolomics associations with T2D have been previously reported for the QMDiab study using the Metabolon HD2 platform ${ }^{38,40}$. 
medRxiv preprint doi: https://doi.org/10.1101/2022.01.13.22269204; this version posted January 13, 2022. The copyright holder for this preprint (which was not certified by peer review) is the author/funder, who has granted medRxiv a license to display the preprint in perpetuity.

All rights reserved. No reuse allowed without permission.

However, here we are using data that has been recently remeasured on the more recent Metabolon HD4 platform in Durham (NC), which is compatible with the QBB metabolomics data annotation. Data for 1,104 metabolites from 309 samples of QMDiab were used. From 194 metabolites that associated with T2D in QBB at a Bonferroni level $(p<0.05 / 1,159)$, data was also available for 175 metabolites in QMDiab. For the replication, the same processing of the metabolomics data was performed, including log-scaling, z-scoring, and outlier winsorization to 5 s.d., before computing the association.

T2D subtype cluster omics and medication analysis. Cluster specific proteins and metabolites were identified using linear models without covariates and following two criteria. First, the omics levels for a given cluster were compared to all others combined, requiring Bonferroni significance levels ( $p<0.05 /$ Nmetabolites and $p<0.05 /$ Nproteins). Second, the omics levels for a given cluster were compared to all other clusters individually, requiring nominal significance $(p<0.05)$. Cluster specific drug usage was identified using a Fisher test comparing usage of a given drug in a given cluster to all other clusters combined, requiring nominal significance $(p<0.05)$.

Replication of associations of T2D subtypes with proteomics. Replication of the subgroup specific proteins was attempted in the ANDIS study ${ }^{8}$ using a linear regression model for each cluster versus all other clusters, while adjusting for sex. Protein levels were measured in the ANDIS study for $\mathrm{N}=176$ individuals (44 individuals per subtype) using the Olink platform (Olink Proteomics, Uppsala, Sweden). Equal numbers of men and women were selected based on Euclidean distance to the cluster centers to be representative of their subtype. All selected individuals were between age 38.1 and 75.2 years, of European decent, and had their blood samples taken within 3 months of diabetes diagnosis. The following 13 Olink panels were used: Olink CARDIOMETABOLIC, Olink CARDIOVASCULAR II, Olink CARDIOVASCULAR III, Olink CELL REGULATION, Olink DEVELOPMENT, Olink IMMUNE RESPONSE, Olink INFLAMMATION, Olink METABOLISM, Olink NEURO EXPLORATORY, Olink NEUROLOGY, Olink ONCOLOGY II, Olink ONCOLOGY III, and Olink ORGAN DAMAGE, covering a total of 1,161 distinct protein assays. The biomarker expression was measured using logarithm of the relative biomarker/protein concentration in each panel, expressed as normalized protein expression (NPX) values. Outlier 
medRxiv preprint doi: https://doi.org/10.1101/2022.01.13.22269204; this version posted January 13, 2022. The copyright holder for this preprint (which was not certified by peer review) is the author/funder, who has granted medRxiv a license to display the preprint in perpetuity.

All rights reserved. No reuse allowed without permission.

analysis was performed using an unsupervised clustering algorithm using a One Class Support Vector Machine. Four samples, one from each subtype, were identified as outliers and excluded from the analysis, leaving $\mathrm{N}=172$ individuals (43 individuals per subtype). Data was available for 30 of the 47 subtype specific proteins (matched by Uniprot identifiers) that were shared between the Olink data in ANDIS and the Somalogic data in QBB.

\section{RESULTS}

The T2D subtype clustering scheme defined for Caucasians can be translated to an Arab population.

Following the approach of Ahlqvist et al. (Figure 1) we used $k$-means clustering of age at diagnosis, BMI, $\mathrm{HbA}_{1 \mathrm{c}}, \mathrm{HOMA2-B}$, and HOMA2-IR and identified four clusters with clinical properties similar to those in the ANDIS study (Figure 2A). The SIDD cluster was characterized by young age at onset, low BMI, low insulin secretion (HOMA2-B) and poor glycemic control (high $\mathrm{HbA}_{1 c}$ ); the SIRD cluster had the highest level of insulin resistance (HOMA2-IR) and high BMI; the MOD cluster had a high BMI with low insulin resistance; and the MARD cluster, like the MOD clusters, had low insulin resistance, but a much lower age of onset of T2D. The relative cluster sizes in QBB were comparable to those found in the ANDIS study, except for SIRD, which made up only $4 \%$ of the T2D cases in QBB compared to $15 \%$ in ANDIS.

We performed several sensitivity tests on the way the clusters were derived. First, we replicated the clustering in an independent testing set within QBB. We obtained very similar results compared to using cluster coordinates from the training set (Figure 2B) and found that cluster assignments were identical for $98 \%$ of the study participants. We then repeated the clustering allowing for a varying number of cluster (Supplementary Figure 4A). Consistent with the observations of Ahlqvist et al., four clusters were identified in QBB (Supplementary Figure 3). Allowing for a fifth cluster led to a split of the MARD cluster into one cluster with a lower and one with a higher age of T2D onset (Supplementary Figure 4A). Repeating the cluster analysis separately for females and males showed that most individuals (93\%) were assigned to the same cluster as in the initial analysis (Supplementary Figure 4B). 
medRxiv preprint doi: https://doi.org/10.1101/2022.01.13.22269204; this version posted January 13, 2022. The copyright holder for this preprint (which was not certified by peer review) is the author/funder, who has granted medRxiv a license to display the preprint in perpetuity.

All rights reserved. No reuse allowed without permission.

HOMA2-IR and HOMA2-B estimates are based on plasma glucose and C-peptide (Cpep) levels and are sensitive to the fasting state. Other studies have reported on clustering using nonfasting values by using HDL-cholesterol and C-peptide, which is a proxy for insulin resistance ${ }^{41}$. As QBB participants were not all in a fully fasting state $(77 \%$ of the individuals had fasted for over two hours at the time of enrolment and $50.7 \%$ had fasted for over 8 hours), we tested the sensitivity of the cluster assignments to self-reported time-since-last-meal. Using linear regression, we estimated fasting HOMA2-IR and HOMA2-B and used the corrected values for clustering. $98 \%$ of the cluster assignments remained unchanged, indicating that the clustering is robust to fasting state (Supplementary Figure 4C).

Finally, we tested whether ANDIS-derived cluster centers could be used directly to classify QBB participants into T2D subtype clusters. We observed consistent cluster assignments for $65 \%$ of the individuals when using the ANDIS-derived cluster centers instead of the QBB-derived cluster centers for classification (Figure $\mathbf{2 C}$ ). In addition, we noted a gender bias in the misclassification with $23 \%$ of misclassified males compared to $46 \%$ of females. A comparison of the cohortspecific cluster centers (standardized values centered to mean=0 and $S D=1$ ) is presented in Supplementary Table 4. Apart, from the age variable, gender-specific variables for the different clusters were directionally consistent between ANDIS and QBB (Supplementary Figure 5). Although the trends of four out of five cluster variables were consistent across the T2D subtypes in both cohorts, the limited overall agreement between T2D subtype classifications obtained using ANDIS versus QBB coordinates suggested that population specific coordinates should be used. We therefore used sex-independent coordinates derived from the QBB training set to classify the QBB training set in the following metabolomics and proteomics analyses.

\section{Metabolomics and proteomics associations with T2D replicate other populations.}

Diabetes-specific alterations of protein and metabolite levels have previously been described in different populations ${ }^{42-45}$. To validate the metabolomic and proteomic data in $\mathrm{QBB}$ and its ability to characterize T2D participants, we investigated omics-associations with T2D. Deep 
medRxiv preprint doi: https://doi.org/10.1101/2022.01.13.22269204; this version posted January 13, 2022. The copyright holder for this preprint (which was not certified by peer review) is the author/funder, who has granted medRxiv a license to display the preprint in perpetuity.

All rights reserved. No reuse allowed without permission.

molecular phenotyping data was available for 420 QBB participants with T2D and 1,735 controls and covered semi-quantitative measures of 1,159 blood circulating metabolites and 1,305 plasma proteins. We compared the protein levels of the T2D cases $(N=420)$ to those of the controls $(\mathrm{N}=1,735)$ in a linear model with covariates as described in the methods. We identified 214 proteins associated with T2D at a Bonferroni level of significance $\left(P<0.05 / 1,305=3.83 \times 10^{-}\right.$ 5) (Figure 3A \& Supplementary Table 5). We checked the associations for replication in the independent European AGES population ( $N=5,457)$. Of 214 proteins associated with T2D in QBB, 107 were also measured on the SOMAscan platform used in AGES. One hundred and four $(97.2 \%)$ of these proteins replicated at a Bonferroni-corrected significance level $(P<0.05 / 107)$. All replicated associations were directionally concordant (Figure 3B).

We further identified 194 metabolites that were associated with T2D $\left(P<0.05 / 1,159=4.31 \times 10^{-}\right.$

$\left.{ }^{5}\right)$ (Figure 3C \& Supplementary Table 6). We confirmed previous T2D associations with sugars (glucose, mannose, 1,5-AG, etc.), with branched chain amino acids (BCAAs) (incl. isoleucine, leucine, valine), various lipids and markers of kidney function. We attempted replication of these T2D-metabolite associations in the multi-ethnic Qatar Metabolomics Study of Diabetes (QMDiab) cohort (Supplementary Table 7). From the 194 T2D associated metabolites identified in QBB, 175 were also measured in QMDiab. All associations were directionally concordant, and $41(23 \%)$ of these associations were statistically significant at a Bonferroni level $(p<0.05 / 175)$ (Figure 3D).

Cluster-specific metabolomics and proteomics associations reveal diabetes subtype-specific processes.

We identified all proteins and metabolites that were differentially expressed in one of the four T2D subtype clusters. We required (1) that their means were different from those of all other clusters combined at a Bonferroni significance level and (2) that their means were different from all other clusters in a pair-wise comparison at a nominal level of significance (see methods). Based on this criterion, 47 proteins and 42 metabolites were specific to a given T2D subtype. Figures 4 and $\mathbf{5}$ represent an overview of the central findings (data in Supplementary 
medRxiv preprint doi: https://doi.org/10.1101/2022.01.13.22269204; this version posted January 13, 2022. The copyright holder for this preprint (which was not certified by peer review) is the author/funder, who has granted medRxiv a license to display the preprint in perpetuity.

All rights reserved. No reuse allowed without permission.

Tables 8 and 9, Figure 6 and Supplementary Figure 7 and 8 have detailed boxplots). In the following we report highlights of these associations and possible rationalizations for the observed subtype specificities. We start with proteins, followed by metabolites, and address which are - in our view - the most interesting findings, always following the same order, that is, SIDD, SIRD, MOD, and then MARD.

We observed subtype-specific elevated levels of Complement C2 (C2) in the SIDD cluster. Type 1 diabetes has a well-established association with HLA antigens ${ }^{46}$ and C2 has been linked to HLA in T1DM ${ }^{47}$. SIDD is most similar to SAID in terms of being the most severely insulin deficient, but is not auto-antibody positive, which is the primary diagnostic feature in SAID. Complement activation extends beyond microbial defense and can be involved in obesity, insulin resistance, diabetes, and dyslipidemia, indicating an inflammatory component ${ }^{48-52}$. Studies have shown that metabolic inflammatory signaling can affect pathways that lead to insulin resistance ${ }^{53,54}$. Accumulating evidence supports activation of the complement system with the development of insulin resistance ${ }^{55}$. The SIRD cluster had the highest levels of insulin (INS) and the lowest levels of insulin-like growth factor-binding protein 1 (IGFBP1). Individuals could develop insulin resistance due to low IGFBP1 which directly affects insulin sensitivity through its RGD domain ${ }^{56}$. Proteins (C59 glycoprotein, inhibin beta A chain, osteomodulin, Follistatin-related protein 3, C27 antigen) specifically dysregulated in SIDD were often also dysregulated in SAID, possibly reflecting shared underlying processes. The MOD cluster had the highest leptin (LEP) levels and enzymes involved in lipid metabolism, such as phospholipase A2 (PLA2G2A) and fatty acid-binding protein (FABP3). The MARD cluster had the highest levels of APOM, APOB, UNC5D, NCAM1, Cystatin-M, and the lowest levels of Plexin-B2 (PLXNB2). All protein levels specific to MARD were closer (or comparable) to those of the controls when compared to the other subtypes, suggesting that MARD individuals were the "healthiest" among the T2D subtypes, and that the proteins associated with MARD are more strongly dysregulated in all other subtypes. 
medRxiv preprint doi: https://doi.org/10.1101/2022.01.13.22269204; this version posted January 13, 2022. The copyright holder for this preprint (which was not certified by peer review) is the author/funder, who has granted medRxiv a license to display the preprint in perpetuity.

All rights reserved. No reuse allowed without permission.

In relation to plasma metabolites, individuals in the SIDD cluster had the lowest 1,5anhydroglucitol (1,5-AG) levels of all groups. 1,5-AG is a marker of short-term glycemic control and is implemented as a clinical test in the GlycoMark ${ }^{\mathrm{TM}}$ assay ${ }^{57}$. The blood sugars mannose, glucose, fructose, mannonate, and gluconate were considerably higher in the SIDD cluster, indicating a greater level of hyperglycemia. Individuals in the SIDD cluster also exhibited elevated levels of cortisone and cortisol, which are stress markers associated with dysregulated glucose metabolism ${ }^{58}$ and a number of chronic complications of $T 2 D^{59}$. We also observed a decrease in the level of dimethylglycine (DMG) in SIDD, a product of betaine catabolism and low betaine and DMG levels, which has been associated with higher glucose levels and the development of $T 2 D^{60}$. Furthermore, the SIDD cluster had decreased levels of gammaglutamyl amino acids (gamma-glutamylphenylalanine and gamma-glutamyltyrosine), indicating perturbed glutathione metabolism. The levels of two sphingomyelin species (sphingomyelin (d18:2/14:0, d18:1/14:1) and sphingomyelin (d18:2/24:2)) were also lower in the SIDD cluster. Downregulated sphingolipid metabolism can affect insulin sensitivity and lead to $\beta$ cell dysfunction ${ }^{61}$.

The SIRD cluster had elevated levels of lipokine-related metabolites, including 12,13-DiHOME, a linoleic acid metabolite, and 2-hydroxyarachidate, an arachidic acid metabolite. 12,13-DiHOME was previously recognized as an important lipid mediator stimulating fatty acid uptake by skeletal muscles ${ }^{62}$, which could serve as an alternative energy source for SIRD subjects given their potentially limited access to glucose, due to insulin resistance. The plasma level of phosphate was lower in the SIRD cluster compared to other clusters, and could potentially be linked to hypophosphatemia which is frequently observed in conditions of diabetic ketoacidosis driven by hyperglycemia-induced osmotic diuresis ${ }^{63}$. Although diabetic ketoacidosis is rare in SIRD, it has been previously reported ${ }^{64}$.

The MOD cluster had high levels of hydroxyasparagine, 5-(galactosylhydroxy)-L-lysine, and 7alpha-hydroxy-3-oxo-4-cholestenoate (7-Hoca), which play a role in lipid metabolism and obesity $^{65}$. The elevated levels of 5-(galactosylhydroxy)-L-lysine, an important post- 
translationally modified amino acid present in collagen-like proteins, such as adiponectin ${ }^{66}$, may be the result of adipogenic collagen turnover ${ }^{67,68}$. Metalloproteinase, MT1-MMP, a pericellular collagenase and a member of the matrix metalloproteinase (MMP) gene family, directs interactions that control adipogenesis ${ }^{67}$ and is critical to white adipose tissue development by remodeling of the 3-D type I collagen scaffolding that dominates primordial white fat deposits. Hence, its absence leads to disruption of transcription factor cascades required for adipocyte maturation and would broadly occur in individuals in the MOD cluster with high BMI. Adiponectin is an important target in obesity treatment, is a key regulator of fatty acid oxidation and lipid synthesis and is well known to decrease triglyceride concentrations and increase insulin sensitivity ${ }^{69}$. Oxysterols play a signaling role in lipid and glucose metabolism which may be implicated in obesity through the control of lipogenesis ${ }^{70,71}$. They also play an important role in cholesterol uptake, transport, excretion, and gene regulation ${ }^{72-74}$. The elevated levels of the oxysterol, 7-Hoca, may be a result of dysregulated fatty acid metabolism and lipid homeostasis.

As in the case of proteins, the metabolic profiles of individuals in the MARD cluster were closest to the controls. Blood carbohydrates levels (glucose and fructose) were higher than normal but were the lowest among the T2D clusters. The levels of glycine, glutamine, histidine, and gamma-glutamyl amino acids (gamma-glutamylglycine, gamma-glutamylglutamine, and gamma-glutamylthreonine) were the lowest in MARD and comparable to individuals without diabetes. Glycine and glutamine are both implicated in insulin secretion ${ }^{75,76}$. Glycine acts on the pancreas through glycine receptors and as a co-ligand for $\mathrm{N}$-methyl-d-aspartate glutamate receptors to control insulin secretion and glutamine regulates beta-cell gene expression, signaling, and insulin secretion. In addition, histidine and gamma-glutamyl amino acids play a role in anti-inflammatory and antioxidative responses ${ }^{77,78}$. Histidine supplementation has been shown to improve insulin resistance by suppressing pro-inflammatory cytokine expression, possibly through the nuclear factor kappa-B (NF-KB) pathway ${ }^{77}$. Serum gammaglutamyltransferase (GGT) is strongly linked to obesity and nonalcoholic fatty liver disease, 
medRxiv preprint doi: https://doi.org/10.1101/2022.01.13.22269204; this version posted January 13, 2022. The copyright holder for this preprint (which was not certified by peer review) is the author/funder, who has granted medRxiv a license to display the preprint in perpetuity.

All rights reserved. No reuse allowed without permission.

which may lead to systemic and hepatic insulin resistance, respectively ${ }^{79}$. Overall, the MARD patients had the least metabolic dysregulation among the T2D subtypes.

Replication of T2D subtype specific protein associations in a different population using a different proteomics platform.

We attempted replication of 30 out of 47 subtype specific protein associations (Supplementary Table 10) using proteomics measurements from the Olink platform in ANDIS. Data was available for 43 individuals in each of the four T2D subgroups $(N=172)$. Four protein associations were replicated after accounting for multiple testing $(p<0.00167 ; 0.05 / 30)$. These were Follistatin-related protein 3 (FSTL3) with the SIDD cluster, Plexin-B2 (PLXNB2) and Cathepsin D (CTSD) with the MARD cluster, and leptin (LEP) with the MOD cluster. Five additional proteins showed concordant directionality at a nominal significance level $(p<0.05)$, that is, CD59 glycoprotein (CD59), Complement C2 (C2) and 72 kDa type IV collagenase (MMP2) with SIDD, Leukemia inhibitory factor receptor (LIF-4) with MOD, and NT-3 growth factor receptor (NTRK-3) with MARD.

\section{Medication patterns are cluster specific.}

Self-reported drug usage was annotated using unique active molecule identifiers obtained from the Drugbank repository ${ }^{80}$ and their corresponding ATC codes. We compared difference in medication usage from all ATC anatomical main and subgroup groups between T2D cases and controls (Table 2). The most common drugs used by patients with T2D were in the ATC anatomical main groups A (Alimentary tract and metabolism) and C (Cardiovascular system). In descending order, the most frequently administered drug subgroups by T2D subjects were A10: Drugs used in diabetes $\left(p=8.70 \times 10^{-220}\right), C 10$ : lipid modifying agents $\left(p=1.04 \times 10^{-64}\right)$, B01: antithrombotic agents $\left(p=2.43 \times 10^{-52}\right), C 07$ : beta blocking agents $\left(p=1.74 \times 10^{-51}\right)$, A01: stomatological preparations $\left(p=7.51 \times 10^{-41}\right)$, N02: analgesics $\left(p=1.17 \times 10^{-39}\right), \mathrm{M} 01$ : anti-inflammatory and antirheumatic products $\left(p=9.40 \times 10^{-32}\right)$, and $c 09$ : agents acting on the renin-angiotensin system $\left(p=3.40 \times 10^{-30}\right)$ (Supplementary Table 11) 
medRxiv preprint doi: https://doi.org/10.1101/2022.01.13.22269204; this version posted January 13, 2022. The copyright holder for this preprint (which was not certified by peer review) is the author/funder, who has granted medRxiv a license to display the preprint in perpetuity.

All rights reserved. No reuse allowed without permission.

The medication patterns were compared across the diabetes subtype clusters in QBB (Supplementary Table 12). Patients in the SIDD cluster were more frequently using insulin (Fisher test $p$-value $\left.=2.62 \times 10^{-4}\right)$, or Metformin $\left(p=1.12 \times 10^{-3}\right)$ and Pioglitazone $\left(3.56 \times 10^{-3}\right)$. SIDD patients were also more frequently prescribed sulfonylureas $\left(p=5.34 \times 10^{-4}\right)$ which increase insulin release, and Sitagliptin $\left(p=6.02 \times 10^{-3}\right)$, a DPP-4 inhibitor that increases glucose dependent insulin release. Patients in the SIRD cluster most frequently took anti-depressant medications $\left(p=5.63 \times 10^{-3}\right)$, medication for diabetic kidney disease e.g. Losartan $\left(p=2.60 \times 10^{-2}\right)$, and medication for rheumatoid arthritis $\left(4.52 \times 10^{-2}\right)$. In the MOD cluster, medications used to treat high blood pressure and heart failure, such as Lisinopril $\left(8.71 \times 10^{-4}\right)$ and esomeprazole $\left(p=3.31 \times 10^{-3}\right)$ were used. The MARD cluster also had the lowest percentage of individuals on insulin treatment $\left(p=2.62 \times 10^{-4}\right)$, whilst perindopril usage was more frequent $\left(4.82 \times 10^{-2}\right)$. 
medRxiv preprint doi: https://doi.org/10.1101/2022.01.13.22269204; this version posted January 13, 2022. The copyright holder for this preprint (which was not certified by peer review) is the author/funder, who has granted medRxiv a license to display the preprint in perpetuity.

All rights reserved. No reuse allowed without permission.

\section{DISCUSSION}

The T2D subtype classification scheme proposed by Ahlqvist el al. ${ }^{8}$ has been replicated in many populations $^{14-17,19-22,81}$ (Supplementary Figure 6), but it may not be generalized to all as shown in an Asian Indian population ${ }^{21}$. Type 2 diabetes has a huge prevalence in the MENA region, with some of the highest rates and predicted increases over the next decade, especially in Qatar (IDF Diabetes Atlas $2021^{82}$ ). No previous study has examined the generalizability of the diabetes cluster classification scheme to Arab populations or characterized it using the latest high-throughput proteomics and metabolomics platforms. All protein and metabolite associations with T2D subtypes are made available as a resource in the Figures and Supplementary files.

Our study shows that the T2D subtypes identified in the Scandinavian population are present in individuals of Arab/Middle Eastern descent. However, the age of diabetes onset in the QBB population was lower compared to ANDIS, especially in the MOD cluster, which could be attributed to the high incidence of obesity in younger Arab individuals. Leptin (LEP) and Follistatin-related protein 3 (FLSTL3) were significantly higher in the MOD cluster and of course increased leptin levels in obesity reflects resistance to leptin action. Also, increased FLSTL3 levels are associated with insulin resistance and have been shown to regulate body composition and glucose homeostasis in human population studies ${ }^{83,84}$. Interestingly, an FLSTL3 knockout mouse has been shown to improve glucose metabolism and increase beta cell mass ${ }^{84}$.

Among the diabetes subtypes, the MARD subtype appeared to be the "healthiest" group and

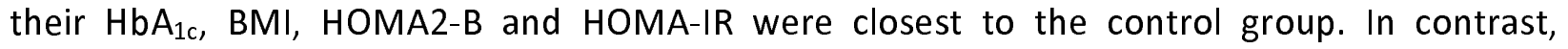
proteins and metabolites that were specific to SIDD were often most similar to those found in the autoimmune (SAID) group. Plexin-B2 (PLXNB2) was the most differentially regulated protein in T2D and this association was further validated in the AGES study ${ }^{23}$. Previous Mendelian randomization studies have suggested that PLXNB2 may have a causal effect on the development of T2D ${ }^{23}$. In the present study, PLXNB2 was lowest in the "healthy" MARD subtype and closest to levels observed in controls. This could make PLXNB2 a potential drug target in individuals with subtypes other than MARD. 
medRxiv preprint doi: https://doi.org/10.1101/2022.01.13.22269204; this version posted January 13, 2022. The copyright holder for this preprint (which was not certified by peer review) is the author/funder, who has granted medRxiv a license to display the preprint in perpetuity.

All rights reserved. No reuse allowed without permission.

Cluster membership has been shown to be associated with individuals who may be more or less prone to the development of long-term complications ${ }^{15,21}$ such as nephropathy ${ }^{8,15,20}$ and fatty liver in SIRD ${ }^{8,15}$, and neuropathy ${ }^{20,22}$ and retinopathy ${ }^{8,20}$ in SIDD. Alterations in protein biomarkers of retinopathy such as antileukoproteinase have been previously reported in the SIDD cluster ${ }^{85}$. We have observed an association between complement factors like Complement C2 (C2), immune-regulatory proteins like $C-C$ motif chemokine 23 (CCL23) and other proteins of the immune system (CD59 glycoprotein (CD59), CD27 antigen (CD27), and Inhibin beta A chain (INHBA), with the SIDD subtype, suggesting that these proteins may play an important feedback role in the resolution of inflammation. A recent review highlighted a paradigm where targeting complement factors may be a possible therapeutic avenue in slowing down diabetic complications ${ }^{55}$. Chemokines also link obesity to inflammation and the subsequent development of insulin resistance ${ }^{86}$. Interestingly, 72 kDa type IV collagenase (MMP-2) was significantly lower in the SIDD subtype. MMP-2 activity has been shown to be lower in rat mesangial cells cultured in high glucose and is believed to contribute to matrix accumulation leading to the development of diabetic nephropathy ${ }^{87}$. Therefore, MMP-2 could potentially be developed into a protein biomarker for nephropathy in SIDD. Plexins are also receptors for semaphorins, a large family of proteins involved in various physiological processes 88. Semaphorins are involved in a number of diabetic complications including diabetic retinopathy, nephropathy, and neuropathy, osteoporosis, and wound healing ${ }^{89}$. Interestingly, we observed significantly higher levels of CD72 in the SIDD subtype and as CD72 appears to mediate the function of semaphorins in some immune cells ${ }^{90}$, it may provide a potential functional link to PLXNB2. Cathepsin D (CTSD) was significantly lower in the MARD subtype and is an aspartic endopeptidase implicated in cell growth, apoptosis and collagen biosynthesis in wounded skin of rats with diabetes and has been correlated with retinopathy and foot ulcers ${ }^{17}$, suggesting that MARD individuals are less likely to develop such complications compared to other subtypes. CTSD also correlates significantly with HOMA-IR and the Tei index, a measure of myocardial performance ${ }^{91}$ and may paradoxically constitute a marker for cardiac dysfunction in 
medRxiv preprint doi: https://doi.org/10.1101/2022.01.13.22269204; this version posted January 13, 2022. The copyright holder for this preprint (which was not certified by peer review) is the author/funder, who has granted medRxiv a license to display the preprint in perpetuity.

All rights reserved. No reuse allowed without permission.

the more "severe" subtypes. However, a biomarker does not implicate causality and there may be a bidirectional relationship which requires further analysis.

Metabolic associations observed with T2D were consistent in magnitude and directionality to previously reported $\mathrm{T} 2 \mathrm{D}$ and pre-diabetes associations ${ }^{92}$. Although elevated blood glucose levels are the defining feature of diabetes mellitus, multiple biochemicals alter the metabolism of fats and amino acids and are associated with impaired insulin action, obesity, and BCAA catabolic enzymatic activity ${ }^{93}$. BCAAs have been consistently linked to T2D development ${ }^{94}$ and we observed alterations in BCAAs and major glucogenic amino acids. Previous studies have shown that cortisol and its metabolite cortisone, were both higher in individuals with diabetes compared to controls and altered cortisol metabolism is specifically characteristic of T2D patients requiring insulin ${ }^{95}$. Consistent with this observation, we observed higher cortisol in the SIDD cluster. Many amino acids have been associated with insulin resistance and decreased insulin secretion, including phenylalanine ${ }^{96}$ and here, in SIRD, we observed significantly higher phenylalanine and 1-carboxyethylphenylalanine. Previous studies have shown that certain lipokines can affect glucose metabolism in adipose, liver, and skeletal muscle tissue ${ }^{97}$. For instance, a lipokine, 12,13-diHOME increases fatty acid uptake and oxidation ${ }^{62}$ and here we show significantly higher 12,13 diHOME in the SIRD cluster. Furthermore, a statistically significant association has been shown between 7-HOCA and asparagine and body mass index $^{98}$. We have observed significantly higher levels of 7-HOCA and hydroxyasparagine in MOD.

The majority of proteins and metabolites which were subtype-specific were also discriminative in previous protein ${ }^{23}$ and metabolite ${ }^{38}$ T2D case-control studies. However, some molecules only distinguished specific subtypes but not cases from controls. This was especially true for the MARD subtype which showed levels similar to the controls. Inhibin beta A chain (INHBA), SPARC-like protein-1 (SPARCL1), and Fibronectin Fragment 4 (FN1) were significantly lower in SIDD compared to other subtypes but were not significantly different between T2D cases and controls. Also, proteins including Leptin (LEP), Phospholipase A2; membrane associated 
medRxiv preprint doi: https://doi.org/10.1101/2022.01.13.22269204; this version posted January 13, 2022. The copyright holder for this preprint (which was not certified by peer review) is the author/funder, who has granted medRxiv a license to display the preprint in perpetuity.

All rights reserved. No reuse allowed without permission.

(PLA2G2A), Follistatin-related protein 3 (FSTL3), and EGF-containing fibulin-like extracellular matrix protein 1 (EFEMP1) were significantly higher in the MOD subtype as they all associate strongly with obesity but did not differentiate between T2D cases and controls when adjusted for BMI.

Studies showing differences in protein biomarkers amongst T2D clusters are limited with the Chinese REACTION study showing that the Angiopoietin-related protein 8 (ANGPTL8) levels were significantly higher in the MARD, SIRD, and SIDD clusters compared to the MOD cluster ${ }^{99}$. We have found a similar trend for both ANGPTL4 and the cell-surface receptor for ANGPTL4 (TEK), two proteins which interact closely with ANGPTL8 ${ }^{100}$. The GDS study ${ }^{16}$, examined 77 protein biomarkers from the Olink inflammation panel and reported lower levels of Protein S100-A12 (EN-RAGE) and IL6 in SIDD compared to the other subtypes. We have also observed lower mean EN-RAGE, Interleukin-6 (IL6), and Interleukin-6 receptor subunit alpha (IL6R) levels in SIDD.

The efficacy of different diabetes drugs would be expected to differ between different subtypes according to the underlying pathophysiology. Hence, we assessed whether ongoing treatment may reflect the clustering of individuals with T2D. Dennis et al. ${ }^{14}$, reported differences in glycemic response among clusters in ADOPT and suggested a benefit in using thiazolidinediones for the SIRD individuals and sulfonylureas for the MARD individuals. However, in this cohort we found that sulfonylurea use was highest in the SIDD and MOD clusters (Supplementary Table 12) whilst thiazolidinedione utilization was infrequent, reflecting reduced prescription of this class in clinical practice, and being paradoxically higher in the SIDD cluster. A current ongoing phase 2 clinical trial is investigating whether the effect of Semaglutide and Dapagliflozin differ between SIDD and SIRD individuals (ClinicalTrials.gov number, NCT04451837). The outcome of such trials may provide insight towards tailored treatment plans and pave the way for personalized medicine in specific subgroups.

We acknowledge some limitations of our current study. The cohort size was relatively small compared to other population-based studies and phenotyping of diabetes complications was 
medRxiv preprint doi: https://doi.org/10.1101/2022.01.13.22269204; this version posted January 13, 2022. The copyright holder for this preprint (which was not certified by peer review) is the author/funder, who has granted medRxiv a license to display the preprint in perpetuity.

All rights reserved. No reuse allowed without permission.

limited to population-study-level questionnaires and biochemical measurements. The deep molecular phenotyping using the SOMAscan and Metabolon technologies provided only relative abundances of protein and metabolite levels respectively, not absolute concentrations. However, this is not a concern for this kind of study. The subtype specific proteins reported here are limited to the specific protein set targeted by the SOMAscan panel, and to protein associations that are detectable in blood. Therefore, the list of subtype specific proteins we report here is not comprehensive, and future studies using other technologies and other biological sample types may reveal further associations. Another limitation is that since GADA was not measured, the SIDD subtype could include some individuals with autoimmune diabetes and may explain the observation of autoimmune features in this group.

In summary, we have identified a wealth of diabetes subtype-specific metabolite and protein signatures which have the potential to identify novel pathways involved in the development and progression of $\mathrm{T} 2 \mathrm{D}$ complications, improve risk prediction, and enable more personalized treatment approaches. Our study adds further support to the medical relevance and clinical applicability of the Ahlvist et al. diabetes subtyping approach.

\section{MANUSCRIPT INFORMATION}

Funding. This study is supported by the Biomedical Research Program at Weill Cornell Medicine in Qatar, a program funded by the Qatar Foundation, and by QNRF grant NPRP11C-0115180010. Qatar Biobank is supported by Qatar Foundation. The statements made herein are solely the responsibility of the authors. EA was funded by grants from the Swedish Research Council (2020-02191) and the Novo Nordisk foundation (NNF180C0034408). Olink measurements in ANDIS were sponsored by Olink Proteomics (Uppsala, Sweden).

Acknowledgements. We are grateful to all study participants of Qatar Biobank for their invaluable contributions to this study. We thank Olle Melander and Rayaz Malek for their suggestions and comments on the present manuscript.

\section{Author contributions}


medRxiv preprint doi: https://doi.org/10.1101/2022.01.13.22269204; this version posted January 13, 2022. The copyright holder for this preprint (which was not certified by peer review) is the author/funder, who has granted medRxiv a license to display the preprint in perpetuity.

Conceived and designed the study: S.Z., K.S.

Analyzed data: S.Z.

Contributed reagents/materials/analysis tools: N.S., M.T.

Wrote the paper: S.Z., A.H, E.A., O.A., A.B.A., K.S.

All authors discussed the results and reviewed the final manuscript.

Data availability. The informed consent given by the study participants does not cover posting of participant level phenotype data in public databases. However, data are available upon request from Qatar Biobank (QBB) (https://www.qatarbiobank.org.qa/research/how-to-apply). Requests are submitted online and are subject to approval by the QBB board.

Ethics approval and consent to participate. Use of the Qatar Biobank data was approved by the QBB IRB under reference Ex-2019-RES-ACC-0160-0083. All study participants provided written informed consent.

Competing interests. The authors declare no competing interests.

Statistical analysis. Statistical analysis was conducted using R and Rstudio.

\section{REFERENCES}

1. Roden M, Shulman GI. The integrative biology of type 2 diabetes. Nature 2019; 576(7785): 51-60.

2. Stumvoll M, Goldstein BJ, van Haeften TW. Type 2 diabetes: principles of pathogenesis and therapy. Lancet 2005; 365(9467): 1333-46.

3. Weyer C, Bogardus C, Mott DM, Pratley RE. The natural history of insulin secretory dysfunction and insulin resistance in the pathogenesis of type 2 diabetes mellitus. $J$ Clin Invest 1999; 104(6): 787-94.

4. American Diabetes A. Standards of medical care for patients with diabetes mellitus. Diabetes Care 2002; 25(1): 213-29.

5. Chaudhury A, Duvoor C, Reddy Dendi VS, et al. Clinical Review of Antidiabetic Drugs: Implications for Type 2 Diabetes Mellitus Management. Front Endocrinol (Lausanne) 2017; 8: 6. 6. Marin-Penalver JJ, Martin-Timon I, Sevillano-Collantes C, Del Canizo-Gomez FJ. Update on the treatment of type 2 diabetes mellitus. World J Diabetes 2016; 7(17): 354-95.

7. American Diabetes A. 9. Pharmacologic Approaches to Glycemic Treatment: Standards of Medical Care in Diabetes-2021. Diabetes Care 2021; 44(Suppl 1): S111-S24. 
medRxiv preprint doi: https://doi.org/10.1101/2022.01.13.22269204; this version posted January 13, 2022. The copyright holder for this preprint (which was not certified by peer review) is the author/funder, who has granted medRxiv a license to display the preprint in perpetuity. All rights reserved. No reuse allowed without permission.

8. Ahlqvist E, Storm P, Karajamaki A, et al. Novel subgroups of adult-onset diabetes and their association with outcomes: a data-driven cluster analysis of six variables. Lancet Diabetes Endocrinol 2018; 6(5): 361-9.

9. Nolan $\mathrm{CJ}$, Prentki M. Insulin resistance and insulin hypersecretion in the metabolic syndrome and type 2 diabetes: Time for a conceptual framework shift. Diabetes $\&$ vascular disease research 2019; 16(2): 118-27.

10. Gloyn AL, Drucker DJ. Precision medicine in the management of type 2 diabetes. Lancet Diabetes Endocrinol 2018; 6(11): 891-900.

11. Udler MS, McCarthy MI, Florez JC, Mahajan A. Genetic Risk Scores for Diabetes Diagnosis and Precision Medicine. Endocrine Reviews 2019; 40(6): 1500-20.

12. Shilo S, Rossman H, Segal E. Axes of a revolution: challenges and promises of big data in healthcare. Nature Medicine 2020; 26(1): 29-38.

13. Harreiter J, Roden M. Diabetes mellitus - Definition, Klassifikation, Diagnose, Screening und Prävention (Update 2019). Wiener klinische Wochenschrift 2019; 131(1): 6-15.

14. Dennis JM, Shields BM, Henley WE, Jones AG, Hattersley AT. Disease progression and treatment response in data-driven subgroups of type 2 diabetes compared with models based on simple clinical features: an analysis using clinical trial data. Lancet Diabetes Endo 2019; 7(6): 442-51.

15. Zaharia OP, Strassburger K, Strom A, et al. Risk of diabetes-associated diseases in subgroups of patients with recent-onset diabetes: a 5-year follow-up study. Lancet Diabetes Endocrinol 2019; 7(9): 684-94.

16. Maalmi H, Herder C, Strassburger K, et al. Differences in biomarkers of inflammation between novel subgroups of patients with recent-onset diabetes. Diabetologia 2020; 63(Suppl 1): S84-S.

17. Ahmad J, Zubair M, Malik A, Siddiqui MA, Wangnoo SK. Cathepsin-D, adiponectin, TNFalpha, IL-6 and hsCRP plasma levels in subjects with diabetic foot and possible correlation with clinical variables: a multicentric study. Foot (Edinb) 2012; 22(3): 194-9.

18. Zou X, Zhou X, Zhu Z, Ji L. Novel subgroups of patients with adult-onset diabetes in Chinese and US populations. The Lancet Diabetes \& Endocrinology 2019; 7(1): 9-11.

19. Li X, Yang S, Cao C, et al. Validation of the Swedish Diabetes Re-Grouping Scheme in Adult-Onset Diabetes in China. The Journal of clinical endocrinology and metabolism 2020; 105(10).

20. Tanabe H, Saito H, Kudo A, et al. Factors Associated with Risk of Diabetic Complications in Novel Cluster-Based Diabetes Subgroups: A Japanese Retrospective Cohort Study. J Clin Med 2020; 9(7).

21. Anjana RM, Baskar V, Nair ATN, et al. Novel subgroups of type 2 diabetes and their association with microvascular outcomes in an Asian Indian population: a data-driven cluster analysis: the INSPIRED study. Bmj Open Diab Res Ca 2020; 8(1).

22. Bello-Chavolla OY, Bahena-Lopez JP, Vargas-Vazquez A, et al. Clinical characterization of data-driven diabetes subgroups in Mexicans using a reproducible machine learning approach. BMJ Open Diabetes Res Care 2020; 8(1).

23. Gudmundsdottir V, Zaghlool SB, Emilsson V, et al. Circulating Protein Signatures and Causal Candidates for Type 2 Diabetes. Diabetes 2020. 
medRxiv preprint doi: https://doi.org/10.1101/2022.01.13.22269204; this version posted January 13 , 2022. The copyright holder for this preprint (which was not certified by peer review) is the author/funder, who has granted medRxiv a license to display the preprint in perpetuity.

All rights reserved. No reuse allowed without permission.

24. Udler MS, Kim J, von Grotthuss M, et al. Type 2 diabetes genetic loci informed by multitrait associations point to disease mechanisms and subtypes: A soft clustering analysis. PLOS Medicine 2018; 15(9): e1002654.

25. Mansour Aly D, Dwivedi OP, Prasad RB, et al. Genome-wide association analyses highlight etiological differences underlying newly defined subtypes of diabetes. Nat Genet 2021; 53(11): 1534-42.

26. Schüssler-Fiorenza Rose SM, Contrepois K, Moneghetti KJ, et al. A longitudinal big data approach for precision health. Nature Medicine 2019; 25(5): 792-804.

27. Al-Goblan AS, Al-Alfi MA, Khan MZ. Mechanism linking diabetes mellitus and obesity. Diabetes Metab Syndr Obes 2014; 7: 587-91.

28. Al Thani A, Fthenou E, Paparrodopoulos S, et al. Qatar Biobank Cohort Study: Study Design and First Results. American Journal of Epidemiology 2019; 188: 1420-33.

29. Al Kuwari H, Al Thani A, Al Marri A, et al. The Qatar Biobank: background and methods. BMC Public Health 2015; 15: 1208.

30. Methodology WCCfDS. Guidelines for ATC classification and DDD assignment 2021. 2021.

31. Gold L, Ayers D, Bertino J, et al. Aptamer-based multiplexed proteomic technology for biomarker discovery. PloS one 2010; 5(12): e15004.

32. Suhre K, Arnold M, Bhagwat AM, et al. Connecting genetic risk to disease end points through the human blood plasma proteome. Nat Commun 2017; 8: 14357.

33. Suhre K, Shin SY, Petersen AK, et al. Human metabolic individuality in biomedical and pharmaceutical research. Nature 2011; 477(7362): 54-60.

34. Evans AM, DeHaven CD, Barrett T, Mitchell M, Milgram E. Integrated, Nontargeted Ultrahigh Performance Liquid Chromatography/Electrospray lonization Tandem Mass

Spectrometry Platform for the Identification and Relative Quantification of the Small-Molecule Complement of Biological Systems. Analytical Chemistry 2009; 81(16): 6656-67.

35. Levy JC, Matthews DR, Hermans MP. Correct homeostasis model assessment (HOMA) evaluation uses the computer program. Diabetes Care 1998; 21(12): 2191-2.

36. Evgenia Dimitriadou AW, Kurt Hornik. Voting in Clustering and Finding the Number of Clusters, 1999.

37. Hennig C. Cluster-wise assessment of cluster stability. Computational Statistics \& Data Analysis 2007; 52(1): 258-71.

38. Yousri NA, Mook-Kanamori DO, Selim MME-D, et al. A systems view of type 2 diabetesassociated metabolic perturbations in saliva, blood and urine at different timescales of glycaemic control. Diabetologia 2015; 58(8): 1855-67.

39. Emilsson V, Ilkov M, Lamb JR, et al. Co-regulatory networks of human serum proteins link genetics to disease. Science 2018; 361(6404): 769-73.

40. Mook-Kanamori DO, Selim MM, Takiddin AH, et al. 1,5-Anhydroglucitol in saliva is a noninvasive marker of short-term glycemic control. The Journal of clinical endocrinology and metabolism 2014; 99(3): E479-83.

41. Slieker RC, Donnelly LA, Fitipaldi $\mathrm{H}$, et al. Replication and cross-validation of type 2 diabetes subtypes based on clinical variables: an IMI-RHAPSODY study. Diabetologia 2021; 64(9): 1982-9. 
medRxiv preprint doi: https://doi.org/10.1101/2022.01.13.22269204; this version posted January 13, 2022. The copyright holder for this preprint (which was not certified by peer review) is the author/funder, who has granted medRxiv a license to display the preprint in perpetuity.

All rights reserved. No reuse allowed without permission.

42. Yousri NA, Mook-Kanamori DO, Selim MM, et al. A systems view of type 2 diabetesassociated metabolic perturbations in saliva, blood and urine at different timescales of glycaemic control. Diabetologia 2015; 58(8): 1855-67.

43. Halama A, Suleiman NN, Kulinski $M$, et al. The metabolic footprint of compromised insulin sensitivity under fasting and hyperinsulinemic-euglycemic clamp conditions in an Arab population. Sci Rep 2020; 10(1): 17164.

44. Halama A, Kahal H, Bhagwat AM, et al. Metabolic and proteomic signatures of hypoglycaemia in type 2 diabetes. Diabetes Obes Metab 2019; 21(4): 909-19.

45. Suhre K, Meisinger C, Doring A, et al. Metabolic Footprint of Diabetes: A Multiplatform Metabolomics Study in an Epidemiological Setting. Plos One 2010; 5(11).

46. Noble JA, Valdes AM. Genetics of the HLA region in the prediction of type 1 diabetes. Curr Diab Rep 2011; 11(6): 533-42.

47. Dornan J, Allan P, Noel EP, Sampson L, Farid NR. Alleles of the second component of complement (C2) in insulin-dependent diabetes mellitus. Hum Hered 1981; 31(4): 211-3.

48. Chawla A, Nguyen KD, Goh YP. Macrophage-mediated inflammation in metabolic disease. Nat Rev Immunol 2011; 11(11): 738-49.

49. Chatzigeorgiou A, Karalis KP, Bornstein SR, Chavakis T. Lymphocytes in obesity-related adipose tissue inflammation. Diabetologia 2012; 55(10): 2583-92.

50. Xu H, Barnes GT, Yang Q, et al. Chronic inflammation in fat plays a crucial role in the development of obesity-related insulin resistance. J Clin Invest 2003; 112(12): 1821-30.

51. Donath MY, Shoelson SE. Type 2 diabetes as an inflammatory disease. Nature Reviews Immunology 2011; 11(2): 98-107.

52. Hotamisligil GS. Inflammation and metabolic disorders. Nature 2006; 444(7121): 860-7.

53. Gao Z, Hwang D, Bataille F, et al. Serine phosphorylation of insulin receptor substrate 1 by inhibitor kappa B kinase complex. J Biol Chem 2002; 277(50): 48115-21.

54. Ozes ON, Akca H, Mayo LD, et al. A phosphatidylinositol 3-kinase/Akt/mTOR pathway mediates and PTEN antagonizes tumor necrosis factor inhibition of insulin signaling through insulin receptor substrate-1. P Natl Acad Sci USA 2001; 98(8): 4640-5.

55. Shim K, Begum R, Yang C, Wang H. Complement activation in obesity, insulin resistance, and type 2 diabetes mellitus. World J Diabetes 2020; 11(1): 1-12.

56. Haywood NJ, Cordell PA, Tang KY, et al. Insulin-Like Growth Factor Binding Protein 1 Could Improve Glucose Regulation and Insulin Sensitivity Through Its RGD Domain. Diabetes 2017; 66(2): 287-99.

57. Dungan KM. 1,5-anhydroglucitol (GlycoMark (TM)) as a marker of short-term glycemic control and glycemic excursions. Expert Rev Mol Diagn 2008; 8(1): 9-19.

58. Dias JP, Joseph JJ, Kluwe B, et al. The longitudinal association of changes in diurnal cortisol features with fasting glucose: MESA. Psychoneuroendocrinology 2020; 119: 104698.

59. Chiodini I, Adda G, Scillitani A, et al. Cortisol secretion in patients with type 2 diabetes: relationship with chronic complications. Diabetes Care 2007; 30(1): 83-8.

60. Magnusson M, Wang TJ, Clish C, et al. Dimethylglycine Deficiency and the Development of Diabetes. Diabetes 2015; 64(8): 3010-6.

61. Khan SR, Manialawy Y, Obersterescu A, Cox BJ, Gunderson EP, Wheeler MB. Diminished Sphingolipid Metabolism, a Hallmark of Future Type 2 Diabetes Pathogenesis, Is Linked to Pancreatic beta Cell Dysfunction. iScience 2020; 23(10): 101566. 
medRxiv preprint doi: https://doi.org/10.1101/2022.01.13.22269204; this version posted January 13, 2022. The copyright holder for this preprint (which was not certified by peer review) is the author/funder, who has granted medRxiv a license to display the preprint in perpetuity.

All rights reserved. No reuse allowed without permission.

62. Stanford KI, Lynes MD, Takahashi H, et al. 12,13-diHOME: An Exercise-Induced Lipokine that Increases Skeletal Muscle Fatty Acid Uptake. Cell Metab 2018; 27(6): 1357.

63. Ditzel J, Lervang HH. Disturbance of inorganic phosphate metabolism in diabetes mellitus: its impact on the development of diabetic late complications. Curr Diabetes Rev 2010; 6(5): 323-33.

64. Robinson C, Cochran E, Gorden P, Brown RJ. Management of Diabetic Ketoacidosis in Severe Insulin Resistance. Diabetes Care 2016; 39(8): e116-8.

65. Snow SJ, Broniowska K, Karoly ED, et al. Offspring susceptibility to metabolic alterations due to maternal high-fat diet and the impact of inhaled ozone used as a stressor. Scientific Reports 2020; 10(1).

66. Herbert KR, Williams GM, Cooper GJ, Brimble MA. Synthesis of glycosylated 5hydroxylysine, an important amino acid present in collagen-like proteins such as adiponectin. Org Biomol Chem 2012; 10(6): 1137-44.

67. Chun TH, Hotary KB, Sabeh F, Saltiel AR, Allen ED, Weiss SJ. A pericellular collagenase directs the 3-dimensional development of white adipose tissue. Cell 2006; 125(3): 577-91. 68. Chun TH, Inoue M, Morisaki H, et al. Genetic Link Between Obesity and MMP14Dependent Adipogenic Collagen Turnover. Diabetes 2010; 59(10): 2484-94.

69. Yamauchi T, Kamon J, Waki $\mathrm{H}$, et al. The fat-derived hormone adiponectin reverses insulin resistance associated with both lipoatrophy and obesity. Nat Med 2001; 7(8): 941-6. 70. Beaven SW, Matveyenko A, Wroblewski K, et al. Reciprocal regulation of hepatic and adipose lipogenesis by liver $\mathrm{X}$ receptors in obesity and insulin resistance. Cell Metab 2013; 18(1): 106-17.

71. Schultz JR, Tu H, Luk A, et al. Role of LXRs in control of lipogenesis. Genes Dev 2000; 14(22): 2831-8.

72. Peet DJ, Turley SD, Ma W, et al. Cholesterol and bile acid metabolism are impaired in mice lacking the nuclear oxysterol receptor LXR alpha. Cell 1998; 93(5): 693-704.

73. Repa JJ, Liang G, Ou J, et al. Regulation of mouse sterol regulatory element-binding protein-1C gene (SREBP-1c) by oxysterol receptors, LXRalpha and LXRbeta. Genes Dev 2000; 14(22): 2819-30.

74. Tontonoz $\mathrm{P}$, Mangelsdorf DJ. Liver $\mathrm{X}$ receptor signaling pathways in cardiovascular disease. Mol Endocrinol 2003; 17(6): 985-93.

75. Yan-Do R, MacDonald PE. Impaired "Glycine"-mia in Type 2 Diabetes and Potential Mechanisms Contributing to Glucose Homeostasis. Endocrinology 2017; 158(5): 1064-73. 76. Corless M, Kiely A, McClenaghan NH, Flatt PR, Newsholme P. Glutamine regulates expression of key transcription factor, signal transduction, metabolic gene, and protein expression in a clonal pancreatic beta-cell line. J Endocrinol 2006; 190(3): 719-27.

77. Feng RN, Niu YC, Sun XW, et al. Histidine supplementation improves insulin resistance through suppressed inflammation in obese women with the metabolic syndrome: a randomised controlled trial. Diabetologia 2013; 56(5): 985-94.

78. Lee DH, Silventoinen K, Jacobs DR, Jr., Jousilahti $P$, Tuomileto J. gamma-

Glutamyltransferase, obesity, and the risk of type 2 diabetes: observational cohort study among 20,158 middle-aged men and women. The Journal of clinical endocrinology and metabolism 2004; 89(11): 5410-4. 
medRxiv preprint doi: https://doi.org/10.1101/2022.01.13.22269204; this version posted January 13, 2022. The copyright holder for this preprint (which was not certified by peer review) is the author/funder, who has granted medRxiv a license to display the preprint in perpetuity.

All rights reserved. No reuse allowed without permission.

79. Marchesini G, Brizi M, Bianchi G, et al. Nonalcoholic fatty liver disease: a feature of the metabolic syndrome. Diabetes 2001; 50(8): 1844-50.

80. Wishart DS, Feunang YD, Guo AC, et al. DrugBank 5.0: a major update to the DrugBank database for 2018. Nucleic Acids Res 2018; 46(D1): D1074-D82.

81. Yang WY, Lu JM, Weng JP, et al. Prevalence of Diabetes among Men and Women in China. New Engl J Med 2010; 362(12): 1090-101.

82. . https://diabetesatlas.org/.

83. Zaghlool SB, Sharma S, Molnar M, et al. Revealing the role of the human blood plasma proteome in obesity using genetic drivers. Nat Commun 2021; 12(1): 1279.

84. Brown ML, Bonomi L, Ungerleider N, et al. Follistatin and follistatin like-3 differentially regulate adiposity and glucose homeostasis. Obesity (Silver Spring) 2011; 19(10): 1940-9.

85. Chee CS, Chang KM, Loke MF, Angela Loo VP, Subrayan V. Association of potential salivary biomarkers with diabetic retinopathy and its severity in type-2 diabetes mellitus: a proteomic analysis by mass spectrometry. PeerJ 2016; 4: e2022.

86. Ota T. Chemokine systems link obesity to insulin resistance. Diabetes Metab J 2013; 37(3): 165-72.

87. Singh R, Song RH, Alavi N, Pegoraro AA, Singh AK, Leehey DJ. High glucose decreases matrix metalloproteinase-2 activity in rat mesangial cells via transforming growth factor-beta1. Exp Nephrol 2001; 9(4): 249-57.

88. Tamagnone L, Artigiani S, Chen $\mathrm{H}$, et al. Plexins are a large family of receptors for transmembrane, secreted, and GPI-anchored semaphorins in vertebrates. Cell 1999; 99(1): 7180.

89. Lu Q, Zhu L. The Role of Semaphorins in Metabolic Disorders. Int J Mol Sci 2020; 21(16).

90. Mizrahi S, Markel G, Porgador A, Bushkin Y, Mandelboim O. CD100 on NK cells enhance IFNgamma secretion and killing of target cells expressing CD72. PLoS One 2007; 2(9): e818.

91. Liu L, Chen B, Zhang X, Tan L, Wang DW. Increased Cathepsin D Correlates with Clinical Parameters in Newly Diagnosed Type 2 Diabetes. Dis Markers 2017; 2017: 5286408.

92. Floegel A, Stefan N, Yu ZH, et al. Identification of Serum Metabolites Associated With Risk of Type 2 Diabetes Using a Targeted Metabolomic Approach. Diabetes 2013; 62(2): 639-48. 93. Adams SH. Emerging Perspectives on Essential Amino Acid Metabolism in Obesity and the Insulin-Resistant State. Adv Nutr 2011; 2(6): 445-56.

94. Wang TJ, Larson MG, Vasan RS, et al. Metabolite profiles and the risk of developing diabetes. Nat Med 2011; 17(4): 448-53.

95. Dullaart RP, Ubels FL, Hoogenberg K, et al. Alterations in cortisol metabolism in insulindependent diabetes mellitus: relationship with metabolic control and estimated blood volume and effect of angiotensin-converting enzyme inhibition. The Journal of clinical endocrinology and metabolism 1995; 80(10): 3002-8.

96. Vangipurapu J, Stancakova A, Smith U, Kuusisto J, Laakso M. Nine Amino Acids Are Associated With Decreased Insulin Secretion and Elevated Glucose Levels in a 7.4-Year Followup Study of 5,181 Finnish Men. Diabetes 2019; 68(6): 1353-8.

97. Hernandez-Saavedra D, Stanford KI. The Regulation of Lipokines by Environmental Factors. Nutrients 2019; 11(10).

98. Moore SC, Playdon MC, Sampson JN, et al. A Metabolomics Analysis of Body Mass Index and Postmenopausal Breast Cancer Risk. J Natl Cancer Inst 2018; 110(6): 588-97. 
medRxiv preprint doi: https://doi.org/10.1101/2022.01.13.22269204; this version posted January 13, 2022. The copyright holder for this preprint (which was not certified by peer review) is the author/funder, who has granted medRxiv a license to display the preprint in perpetuity.

All rights reserved. No reuse allowed without permission.

99. Zou HJ, Duan W, Zhang ZQ, Chen X, Lu PH, Yu XF. The circulating ANGPTL8 levels show differences among novel subgroups of adult patients with diabetes and are associated with mortality in the subsequent 5 years. Scientific Reports 2020; 10(1).

100. Guo C, Zhao Z, Deng X, Chen Z, Tu Z, Yuan G. Regulation of angiopoietin-like protein 8 expression under different nutritional and metabolic status. Endocr J 2019; 66(12): 1039-46. 


\section{TABLES}

Table 1. Demographics of the QBB Diabetes and control groups. The clinical traits that are marked with an asterisk were computed for individuals who fasted for eight or more hours at the time of blood drawing. HOMA2-IR: homeostasis model of assessment of insulin resistance. HOMA2-B: homeostasis model assessment of beta cell function. Family history is defined as either parent having a history record of diabetes. The data are number (\%) or means (SD), as appropriate, $\mathrm{p}$-values are from Fisher or student t-tests for categorical or continuous variables, respectively.

\begin{tabular}{|l|l|l|l|}
\hline Trait & Diabetes & Controls & p-value \\
\hline Sample size (N=4,895) & & & \\
\hline Sex (male) & 1,051 & 3,844 & - \\
\hline Age (years) & $444(42.2 \%)$ & $1,635(34.5 \%)$ & 0.895 \\
\hline BMI (kg/m2) & $51.2(11.3)$ & $34.8(10.4)$ & $5.96 \times 10^{-261}$ \\
\hline Systolic BP (mmHg) & $32.2(5.9)$ & $28.2(5.8)$ & $7.66 \times 10^{-78}$ \\
\hline Diastolic BP (mmHg) & $125.3(16.5)$ & $110.9(13.1)$ & $2.28 \times 10^{-101}$ \\
\hline HbA (\%) $^{\text {(m) }}$ & $71.2 .3(11.3)$ & $67.4(10.2)$ & $2.63 \times 10^{-18}$ \\
\hline Triglycerides (mmol/L) & $7.5(1.8)$ & $5.2(0.3)$ & $2.47 \times 10^{-223}$ \\
\hline LDL-C (mmol/L) & $1.7(1.1)$ & $1.1(0.7)$ & $2.89 \times 10^{-54}$ \\
\hline HDL-C (mmol/L) & $2.9(1.0)$ & $2.9(0.9)$ & $2.32 \times 10^{-2}$ \\
\hline Total cholesterol (mmol/L) & $1.3(0.3)$ & $1.4(0.4)$ & $7.68 \times 10^{-33}$ \\
\hline HOMA2-IR * & $4.9(1.0)$ & $4.9(0.9)$ & 0.463 \\
\hline HOMA2-IR (all data) & $2.1(1.9)$ & $1.2(0.7)$ & $3.47 \times 10^{-23}$ \\
\hline HOMA2-B (\%) * & $2.8(3.1)$ & $1.6(1.6)$ & $1.06 \times 10^{-34}$ \\
\hline HOMA2-B (\%) (all data) & $66.6(54.1)$ & $104.9(35.9)$ & $1.15 \times 10^{-46}$ \\
\hline CPEP (nmol/L) & $76.4(64.5)$ & $120.9(62.4)$ & $4.27 \times 10^{-77}$ \\
\hline Random Glucose (mg/dL) & $1.0(0.6)$ & $0.8(0.5)$ & $2.04 \times 10^{-30}$ \\
\hline Fasting Glucose (mg/dL) * & $161.1(72.3)$ & $90.2(10.3)$ & $1.59 \times 10^{-155}$ \\
\hline Fasting Insulin (pmol/L) * & $154.1(62.7)$ & $90.8(8.7)$ & $2.91 \times 10^{-86}$ \\
\hline Insulin (pmol/L) (all data) & $120.7(270.1)$ & $65.8(41.4)$ & $2.75 \times 10^{-6}$ \\
\hline Fasting time >8hours & $146.9(266.1)$ & $86.0(100.7)$ & $1.08 \times 10^{-12}$ \\
\hline & $555(52.8 \%)$ & $1925(40.6 \%)$ & 0.095 \\
\hline
\end{tabular}


medRxiv preprint doi: https://doi.org/10.1101/2022.01.13.22269204; this version posted January 13, 2022. The copyright holder for this preprint (which was not certified by peer review) is the author/funder, who has granted medRxiv a license to display the preprint in perpetuity. All rights reserved. No reuse allowed without permission.

\begin{tabular}{|c|c|c|c|}
\hline Family history of diabetes & $796(75.7 \%)$ & $2491(64.8 \%)$ & $1.86 \times 10^{-10}$ \\
\hline Creatinine $(\mu \mathrm{mol} / \mathrm{I})$ & $63.2(18.3)$ & $67.6(34.4)$ & $2.83 \times 10^{-7}$ \\
\hline eGFR (mL/min/1.73m2) & $99.4(17.7)$ & $112.9(14.1)$ & $1.29 \times 10^{-98}$ \\
\hline \multicolumn{4}{|l|}{ Smoking } \\
\hline MQ: Current smoker (cigarettes, cigar, pipe) & $107(10.2 \%)$ & $687(14.5 \%)$ & $2.69 \times 10^{-9}$ \\
\hline MQ: Current smoker (water pipe) & $65(15.5 \%)$ & $477(21.1 \%)$ & $2.99 \times 10^{-2}$ \\
\hline MQ: Second-hand smoker & $273(26.0 \%)$ & $1274(26.9 \%)$ & $1.21 \times 10^{-5}$ \\
\hline MQ: Second-hand shisha smoker & $191(18.2 \%)$ & $1079(22.8 \%)$ & $3.86 \times 10^{-11}$ \\
\hline \multicolumn{4}{|l|}{ Physical Activity } \\
\hline MQ: Exercise - (>3hr/week moderate or $>1 \mathrm{hr} /$ week heavy) & $82(7.8 \%)$ & $805(17.0 \%)$ & $1.76 \times 10^{-22}$ \\
\hline MQ: Exercise - (>0hr/week moderate or >0hr/week heavy) & $136(12.9 \%)$ & $1177(24.8 \%)$ & $3.15 \times 10^{-30}$ \\
\hline
\end{tabular}


Table 2. Numbers and percentages for drugs taken by the T2D cases versus controls according to ATC anatomical main groups.

\begin{tabular}{|c|l|c|c|c|}
\hline ID & Anatomical main group & $\begin{array}{c}\text { T2D } \\
\mathbf{( N = 4 2 0})\end{array}$ & $\begin{array}{c}\text { No T2D } \\
\mathbf{( N = 1 , 7 3 5 )}\end{array}$ & p-value \\
\hline A & ALIMENTARY TRACT AND METABOLISM & $273(65.0 \%)$ & $240(13.8 \%)$ & $1.53 \times 10^{-107}$ \\
\hline B & BLOOD AND BLOOD FORMING ORGANS & $98(23.3 \%)$ & $104(6.0 \%)$ & $2.07 \times 10^{-27}$ \\
\hline C & CARDIOVASCULAR SYSTEM & $151(36.0 \%)$ & $125(7.2 \%)$ & $8.33 \times 10^{-56}$ \\
\hline D & DERMATOLOGICALS & $4(1.0 \%)$ & $33(1.9 \%)$ & 0.256 \\
\hline G & GENITO URINARY SYSTEM AND SEX HORMONES & $61(14.5 \%)$ & $95(5.5 \%)$ & $2.68 \times 10^{-10}$ \\
\hline H & SYSTEMIC HORMONAL PREPARATIONS, EXCL. SEX & $46(11.0 \%)$ & $112(6.5 \%)$ & $2.15 \times 10^{-3}$ \\
& HORMONES AND INSULINS & & & \\
\hline J & ANTIINFECTIVES FOR SYSTEMIC USE & $3(0.7 \%)$ & $4(0.2 \%)$ & 0.278 \\
\hline L & ANTINEOPLASTIC AND IMMUNOMODULATING & $6(1.4 \%)$ & $31(1.8 \%)$ & 0.766 \\
& AGENTS & & & \\
\hline M & MUSCULO-SKELETAL SYSTEM & $104(24.8 \%)$ & $120(6.9 \%)$ & $1.51 \times 10^{-26}$ \\
\hline N & NERVOUS SYSTEM & $79(18.8 \%)$ & $71(4.1 \%)$ & $6.43 \times 10^{-26}$ \\
\hline P & ANTIPARASITIC PRODUCTS, INSECTICIDES AND & $1(0.2 \%)$ & $2(0.1 \%)$ & 0.962 \\
& REPELLENTS & $13(3.1 \%)$ & $48(2.8 \%)$ & 0.841 \\
\hline R & RESPIRATORY SYSTEM & $16(3.8 \%)$ & $36(2.1 \%)$ & 0.057 \\
\hline S & SENSORY ORGANS & $4(0.2 \%)$ & 0.733 \\
\hline V & VARIOUS & & \\
\hline
\end{tabular}


medRxiv preprint doi: https://doi.org/10.1101/2022.01.13.22269204; this version posted January 13, 2022. The copyright holder for this preprint (which was not certified by peer review) is the author/funder, who has granted medRxiv a license to display the preprint in perpetuity.

All rights reserved. No reuse allowed without permission.

\section{FIGURES}

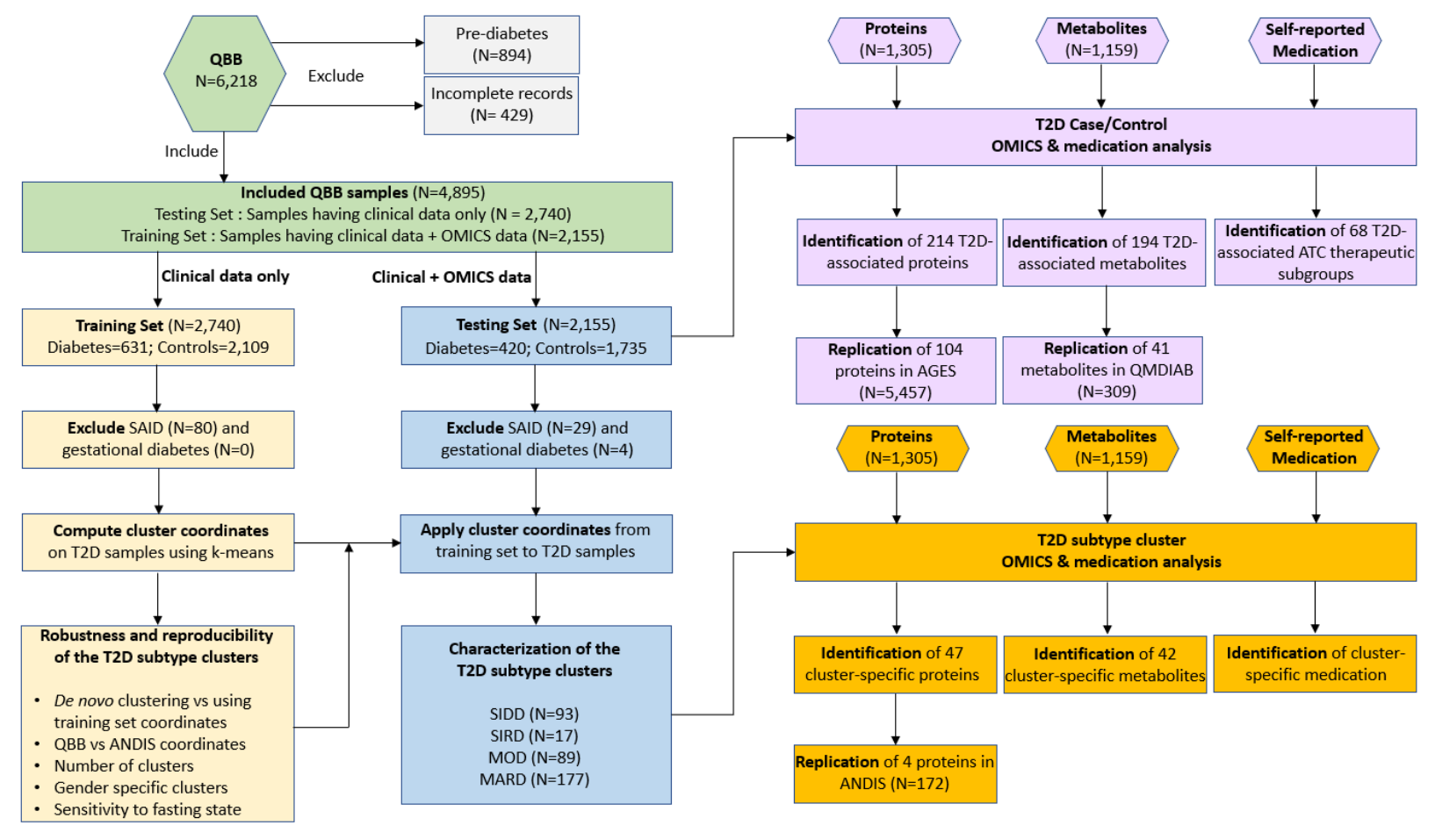

Figure 1. Study flow. 

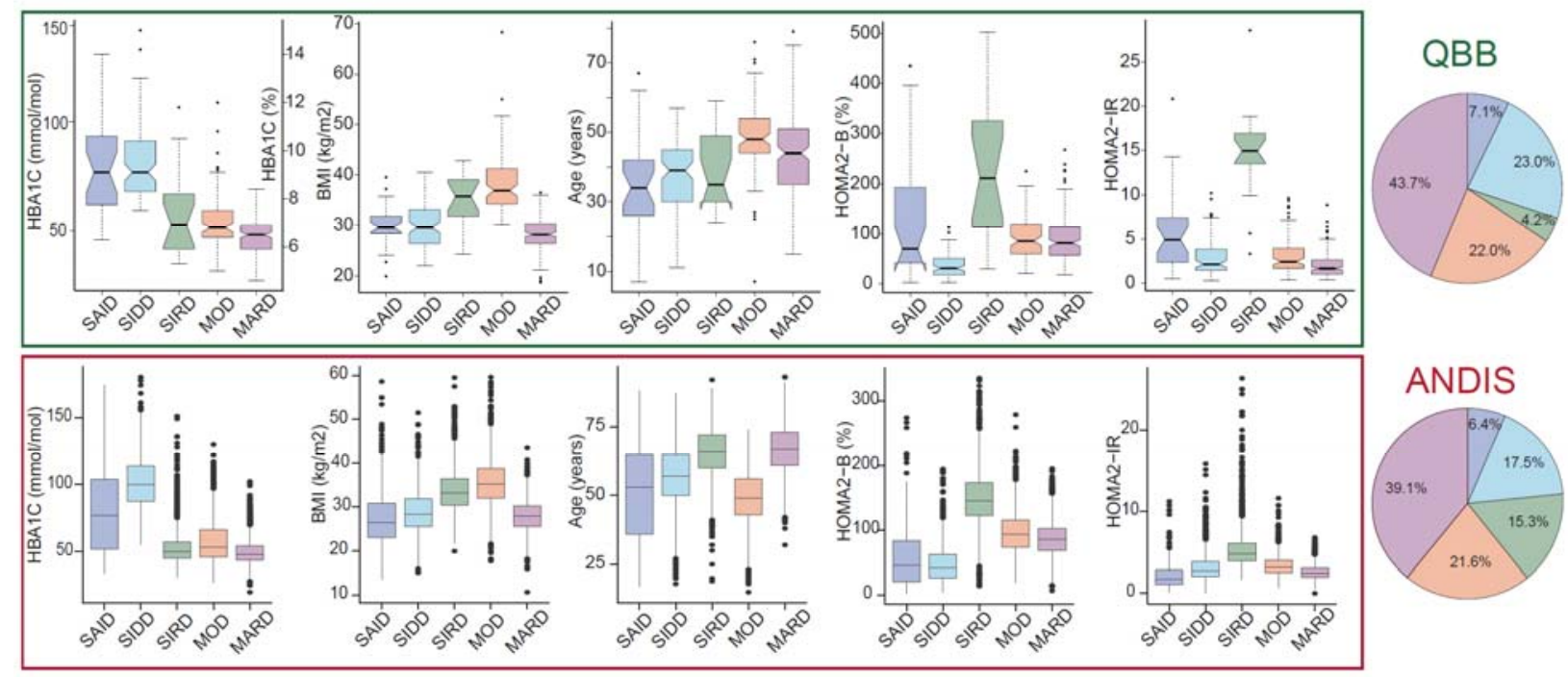

ANDIS

(A)

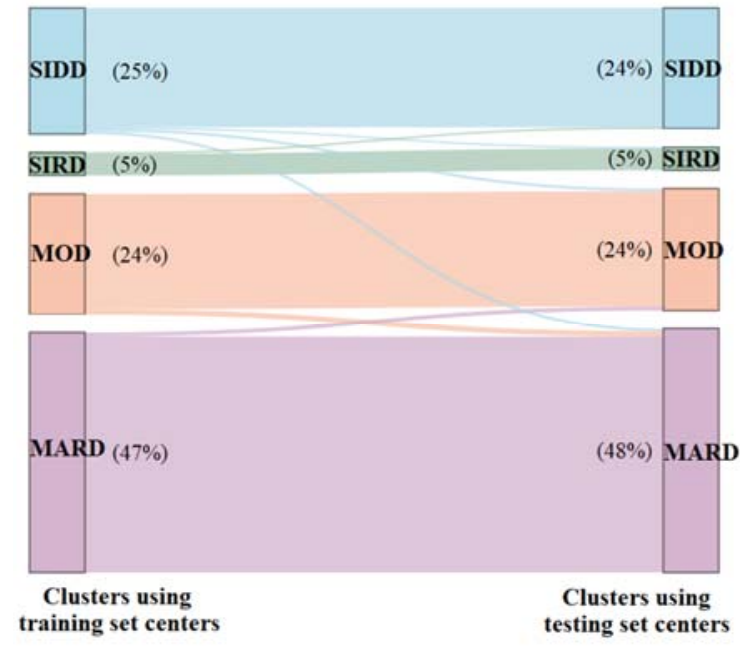

(B)

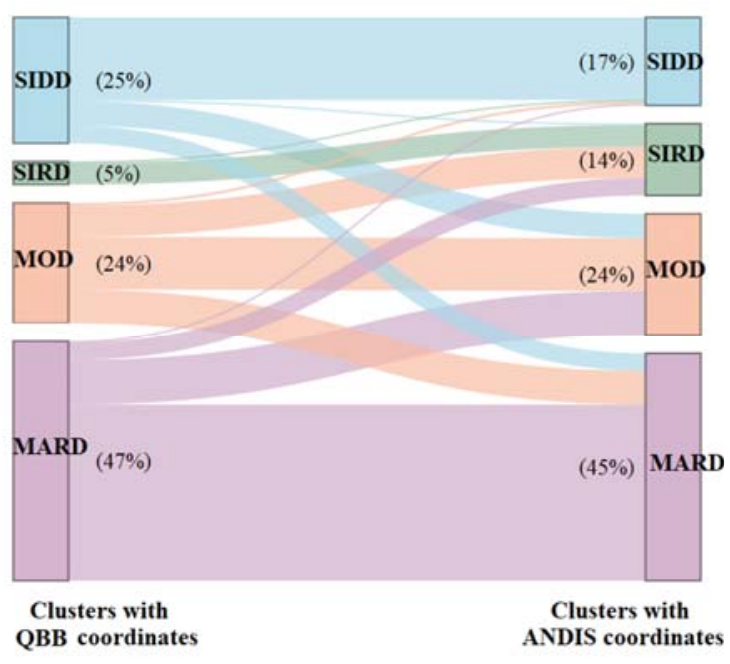

(C)

Figure 2. Cluster characteristics and cluster distribution in QBB. K-means clusters were derived using the QBB training set and classification was applied to the testing set using the training set cluster coordinates. A) Distributions of $\mathrm{HbA}_{1 c}, \mathrm{BMI}$, age, HOMA2-B, and HOMA2-IR are shown for each cluster in QBB and ANDIS. $\mathrm{HbA}_{1 \mathrm{c}}$, BMI, HOMA2-B, and HOMA2-IR all followed the same trend in QBB and ANDIS, but individuals in the MOD cluster were younger than the other clusters in QBB. B) The testing set clusters were similar to the training set clusters, regardless of whether they were assigned based on the training set coordinate centers or derived de novo 
medRxiv preprint doi: https://doi.org/10.1101/2022.01.13.22269204; this version posted January 13, 2022. The copyright holder for this preprint (which was not certified by peer review) is the author/funder, who has granted medRxiv a license to display the preprint in perpetuity. All rights reserved. No reuse allowed without permission.

for the testing set using K-means clustering. Minor changes in the cluster assignments (2\%) were observed when clustering the data using the training set coordinates versus the testing set coordinates. C) After using the ANDIS coordinates instead of the QBB coordinates to classify QBB patients, 35\% changes in the cluster assignments were observed. 


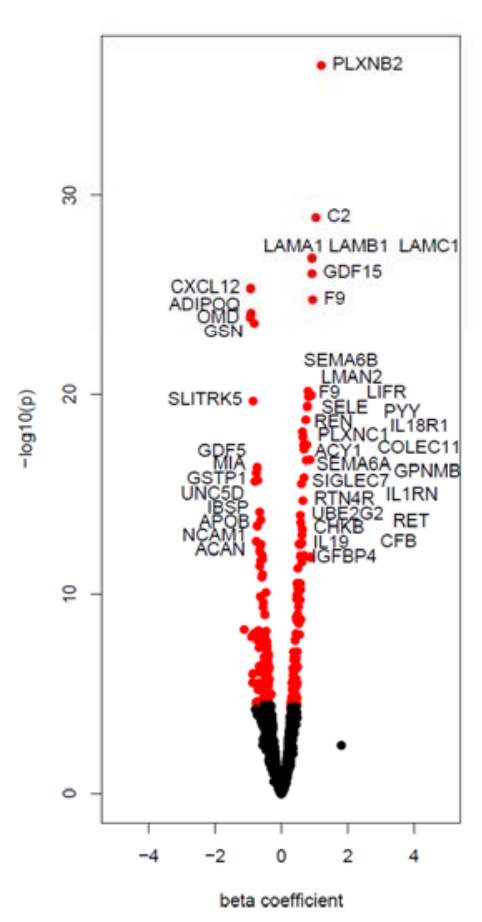

A
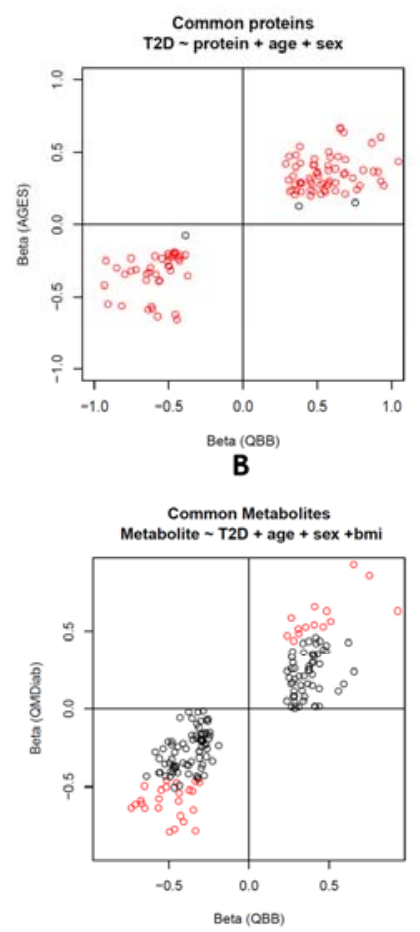

D

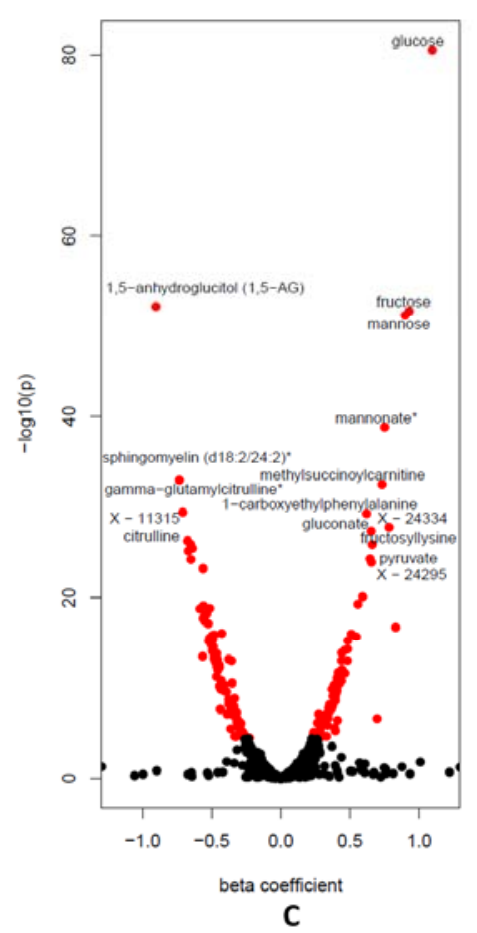

C

Figure 3. Associations of proteomics and metabolomics levels with T2D. A) 214 proteins were significantly associated ( $p<0.05 / 1,305)$ with T2D in QBB after adjusting for age and sex. B) Comparison of effect sizes between QBB and AGES. The replication status of 107 common proteins is shown red: Bonferroni significant $(p<0.05 / 107)$ in both studies, black: significant only in QBB. C) 194 metabolites were significantly associated ( $p<0.05 / 1,159)$ with T2D after adjusting for age, sex, and bmi. D) Comparison between QBB and QMDiab. The replication status of the 175 common metabolites is shown in red/black - Bonferroni significant $(p<0.05 / 175)$ or significant only in QBB. 

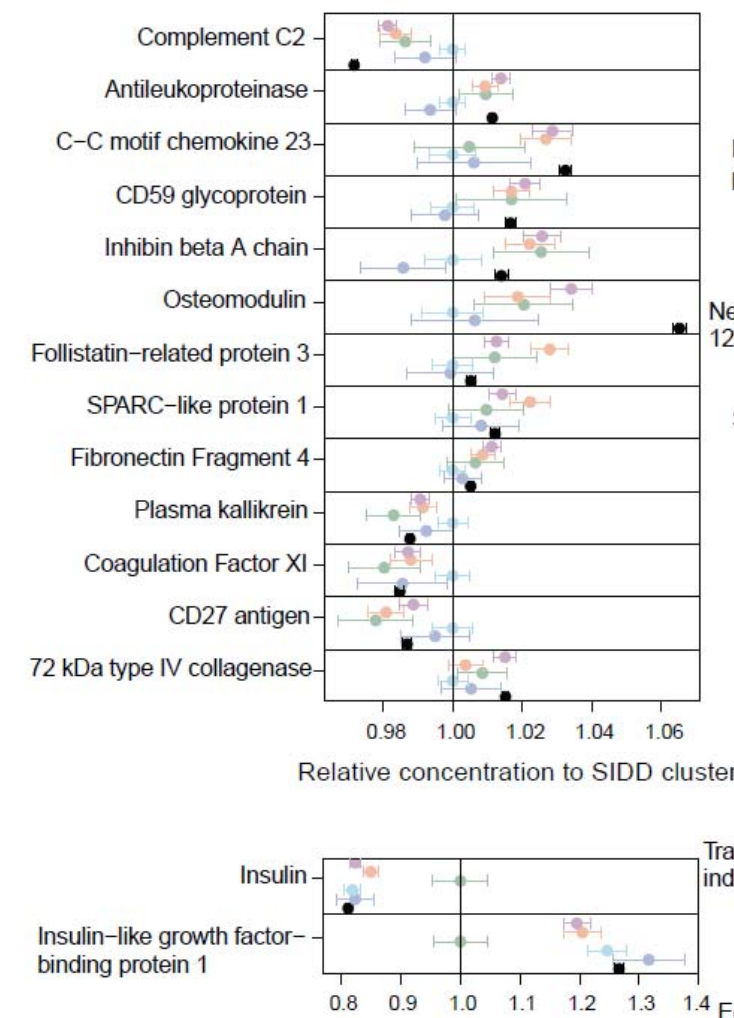

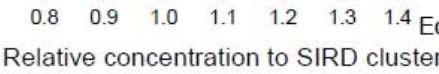

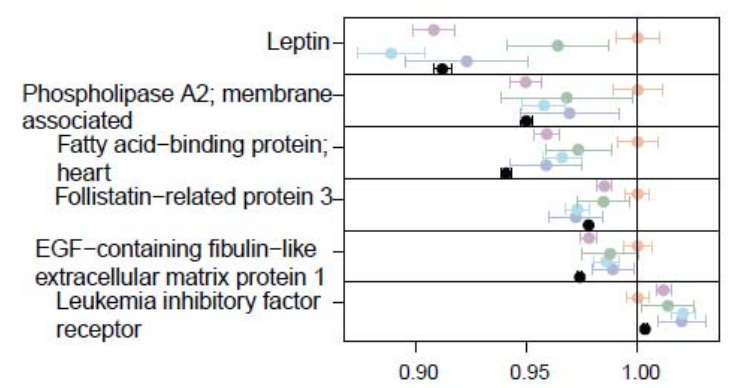

Relative concentration to MOD cluster

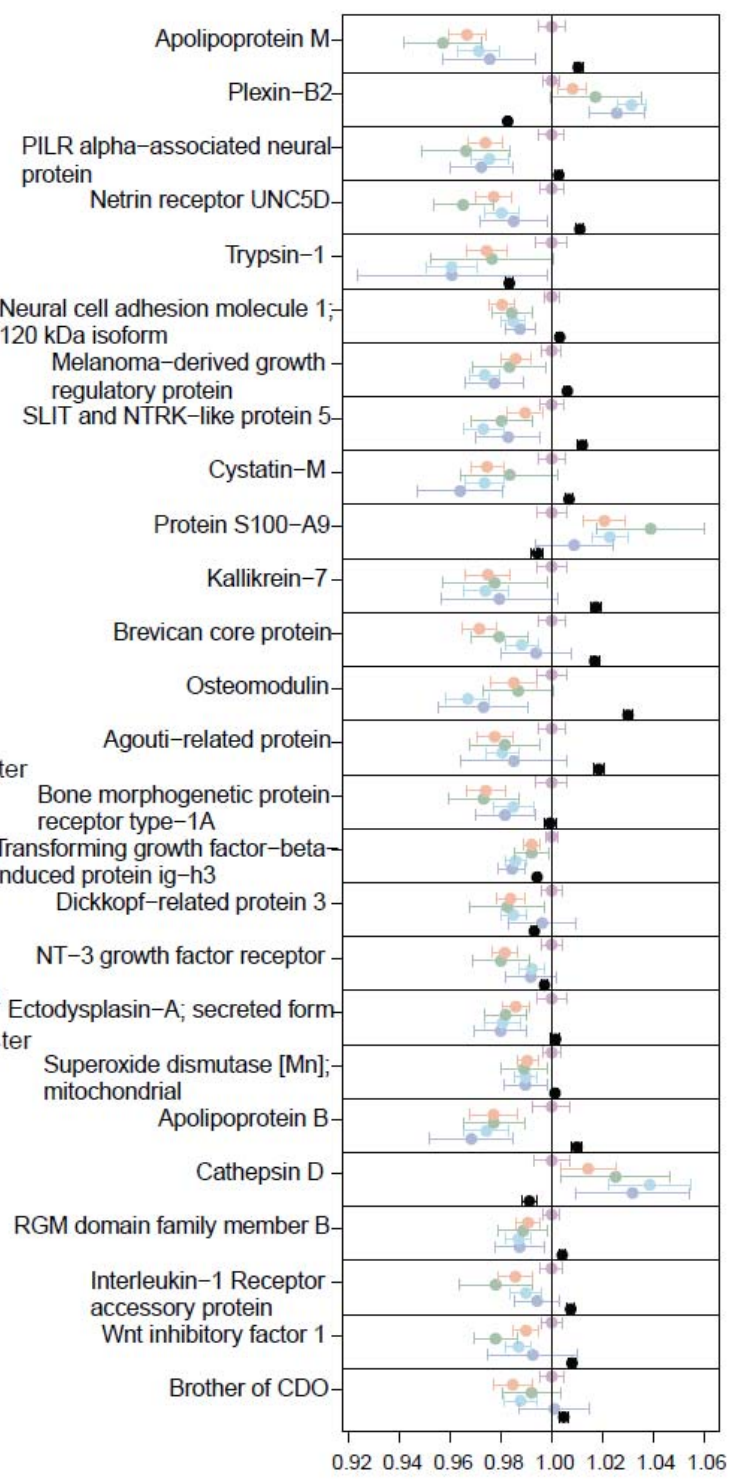

Relative concentration to MARD cluster

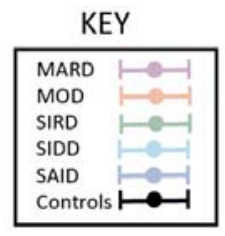

Figure 4. Proteins that distinguish individual diabetes subtypes. The dots and bars represent the mean protein values and the $95 \%$ confidence intervals of the means for proteins that are different in one of the four T2D subtypes compared to all others. Values are normalized by the mean of the respective reference subtype. In addition, data for SAID and the control group are shown for reference. 
medRxiv preprint doi: https://doi.org/10.1101/2022.01.13.22269204; this version posted January 13, 2022. The copyright holder for this preprint (which was not certified by peer review) is the author/funder, who has granted medRxiv a license to display the preprint in perpetuity. All rights reserved. No reuse allowed without permission.

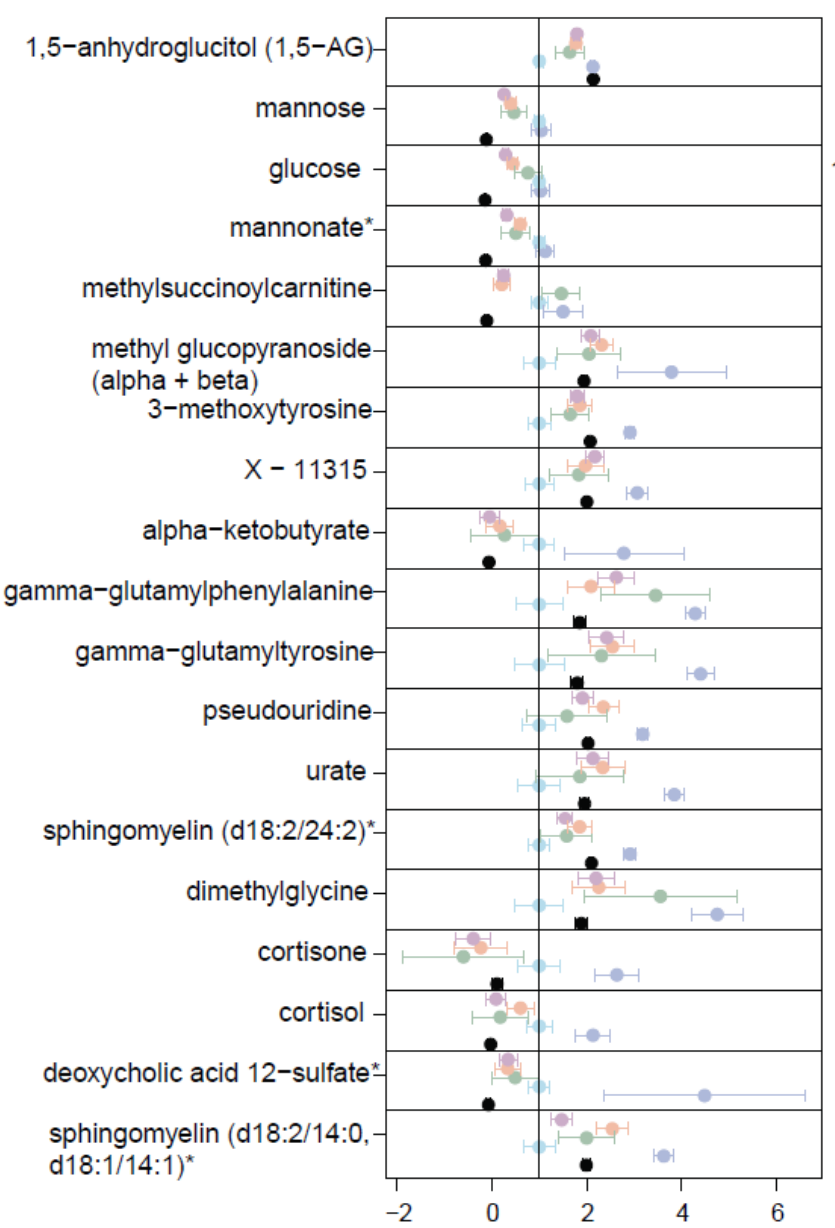

Relative concentration to SIDD cluster

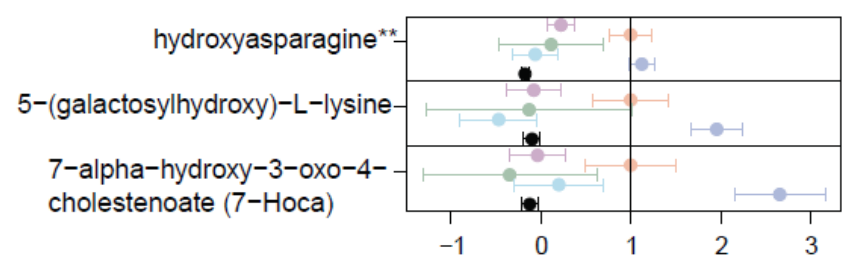

Relative concentration to MOD cluster

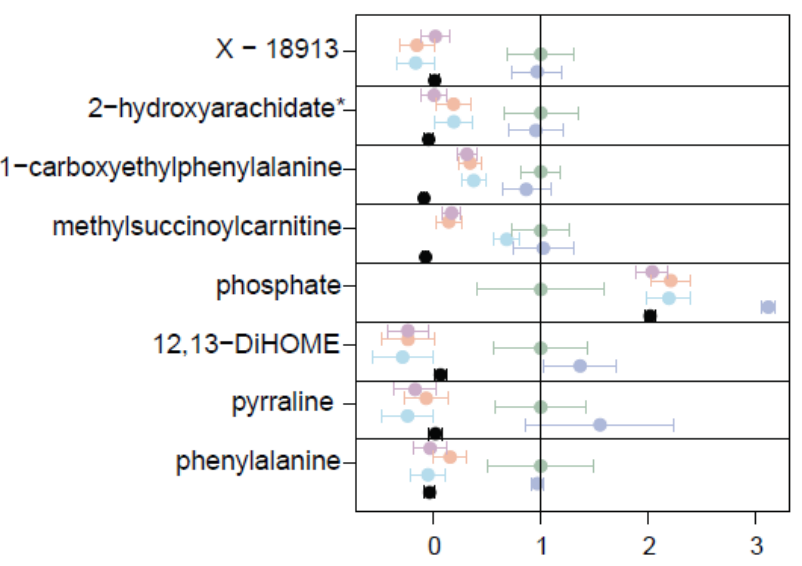

Relative concentration to SIRD cluster

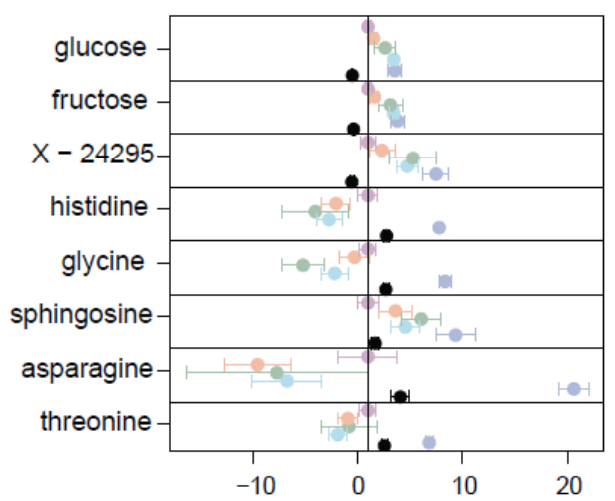

gamma-glutamylglycine glutamine gamma-glutamylglutamine

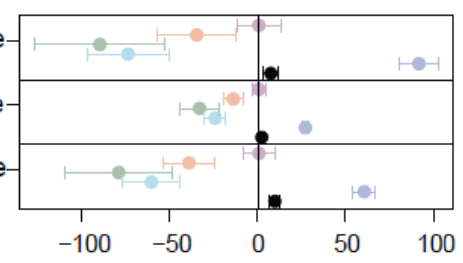
gamma-glutamylthreonine

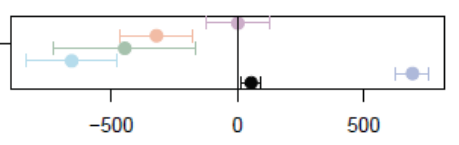

Relative concentration to MARD cluster

\begin{tabular}{|l|}
\multicolumn{1}{c}{ KEY } \\
\hline MARD \\
MOD \\
SIRD \\
SIDD \\
SAID \\
Controls \\
\hline
\end{tabular}

Figure 5. Metabolites that distinguish individual diabetes subtypes. The dots and bars represent the mean metabolite values and the $95 \%$ confidence intervals of the means for metabolites that are different in one of the four T2D subtypes compared to all others. Values 
medRxiv preprint doi: https://doi.org/10.1101/2022.01.13.22269204; this version posted January 13, 2022. The copyright holder for this preprint (which was not certified by peer review) is the author/funder, who has granted medRxiv a license to display the preprint in perpetuity.

All rights reserved. No reuse allowed without permission.

are normalized by the mean of the respective reference cluster. In addition, SAID and the control group are shown for reference. 

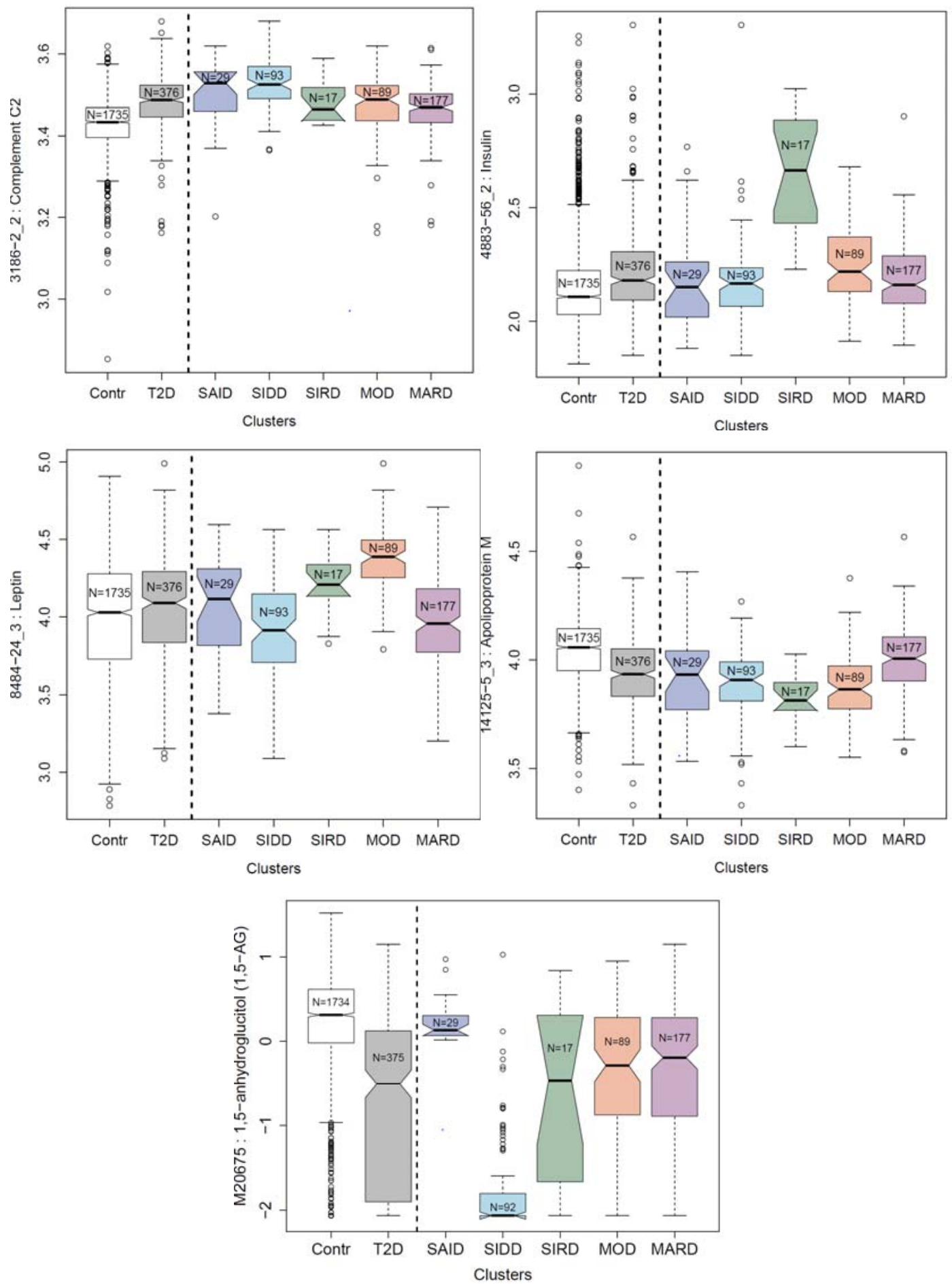

Figure 6. Boxplots of the significantly altered proteins or metabolites in specific diabetes subtypes. Complement C2 (C2) insulin (INS), leptin (LEP), and Apolipoprotein M (APOM) are significantly higher in SIDD, SIRD, MOD, and MARD, respectively, while 1,5 AG is significantly 
medRxiv preprint doi: https://doi.org/10.1101/2022.01.13.22269204; this version posted January 13, 2022. The copyright holder for this preprint (which was not certified by peer review) is the author/funder, who has granted medRxiv a license to display the preprint in perpetuity.

All rights reserved. No reuse allowed without permission.

lower in SIDD. The complete set of box plots for all protein and metabolite levels for each cluster are in Supplementary Figure 7 and 8. 
medRxiv preprint doi: https://doi.org/10.1101/2022.01.13.22269204; this version posted January 13, 2022. The copyright holder for this preprint (which was not certified by peer review) is the author/funder, who has granted medRxiv a license to display the preprint in perpetuity.

All rights reserved. No reuse allowed without permission.

\section{SUPPLEMENTARY FIGURES}

Insulin Treatment

28

32

Tablet Treatment

132

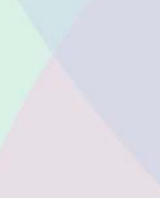

12

1

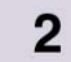

0

2

$21 \quad 10$

40

Supplementary Figure 1. Counts of treatment types for individuals with diabetes. Most individuals with a doctor diagnosis of diabetes were exclusively on tablet treatment, while others were on some combination of insulin, diet and/or physical activity. 

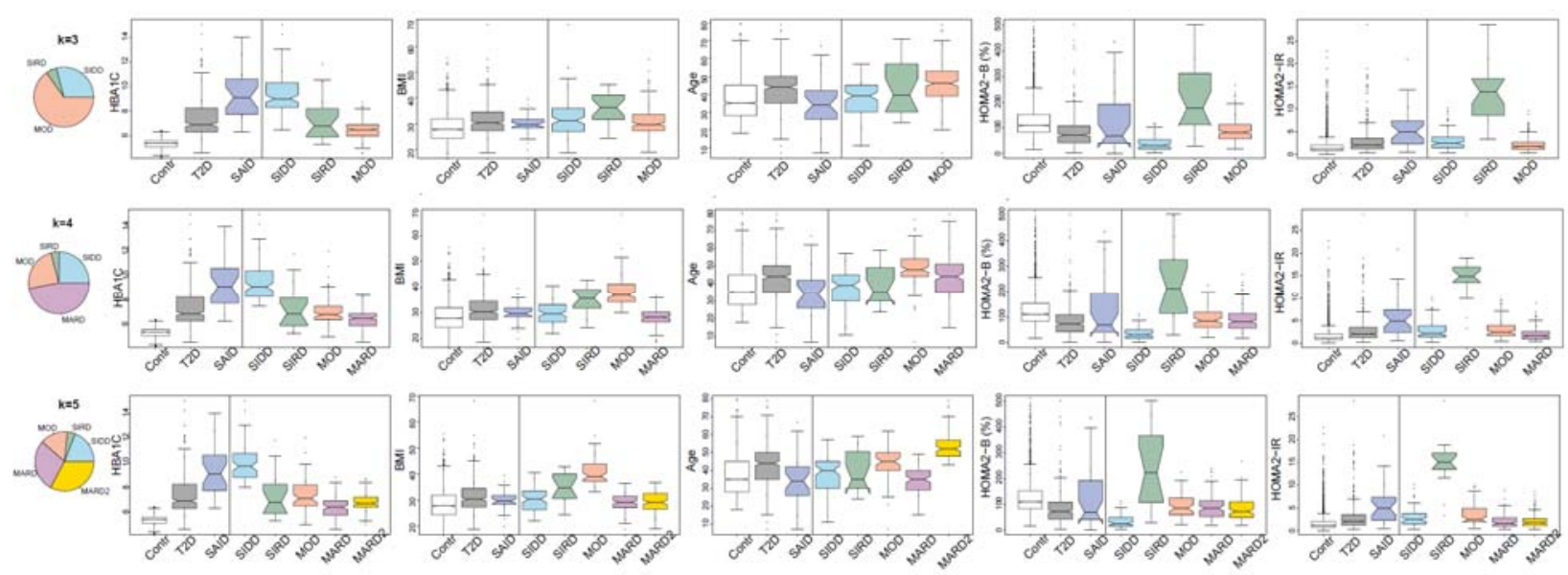

Supplementary Figure 2. Changes in cluster distribution for different $k$. Some changes can be observed in the cluster assignments when clustering QBB data using different $\mathrm{k}(3,4$, and 5$)$. The most prominent change is seen in the split of the MOD cluster to discriminate between older and younger individuals. SAID and control data were not included in the clustering but are visualized for comparison with $\mathrm{T} 2 \mathrm{D}$ and the individual clusters. 


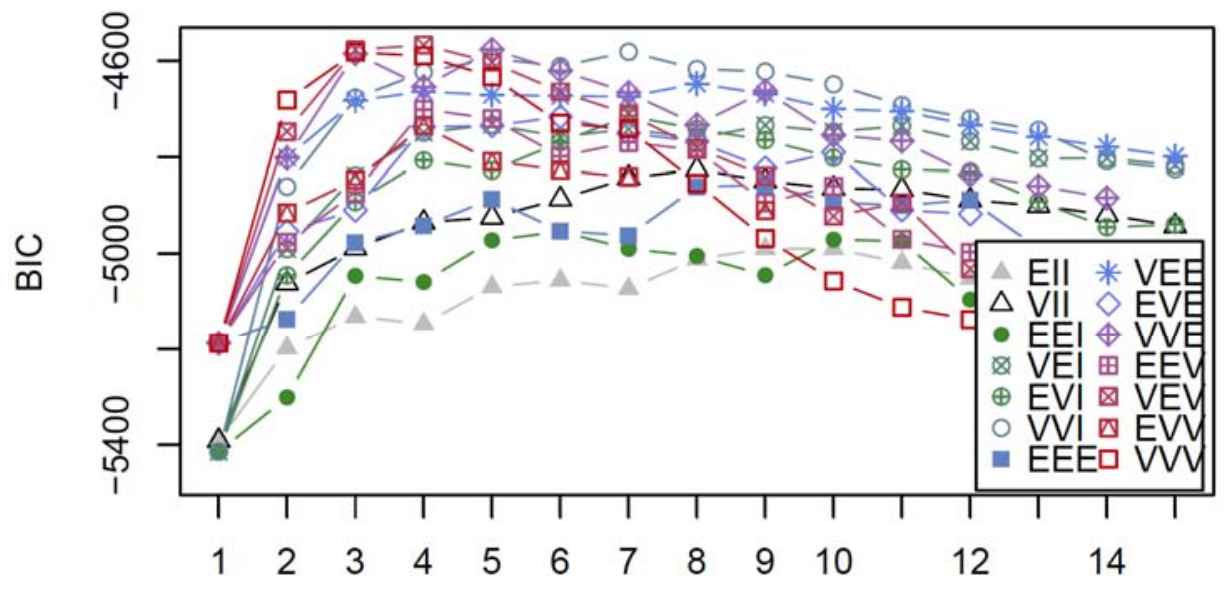

Number of components

Supplementary Figure 3. Data-driven clustering based on Gaussian mixture models. Models are estimated by the expectation-maximization (EM) algorithm initialized by hierarchical modelbased agglomerative clustering. The optimal model and number of clusters was determined using the Bayesian Information Criterion (BIC) for EM. The top 3 models based on the $\mathrm{BIC}$ criterion, were $k=3, k=4$, and $k=5$. The spherical and diagonal models fitted in the EM phase of clustering are shown above. The three-character code represents the volume, shape, and orientation. The codes represent the following multivariate mixture models, "Ell": spherical, equal volume, "VII": spherical, unequal volume, "EEI": diagonal, equal volume and shape, "VEI": diagonal, varying volume, equal shape, "EVI": diagonal, equal volume, varying shape, "VVI": diagonal, varying volume and shape, "EEE": ellipsoidal, equal volume, shape, and orientation, "VEE": ellipsoidal, equal shape and orientation, "EVE": ellipsoidal, equal volume and orientation, "VVE": ellipsoidal, equal orientation, "EEV": ellipsoidal, equal volume and equal shape, "VEV": ellipsoidal, equal shape, "EVV": ellipsoidal, equal volume, "VVV": ellipsoidal, varying volume, shape, and orientation. 


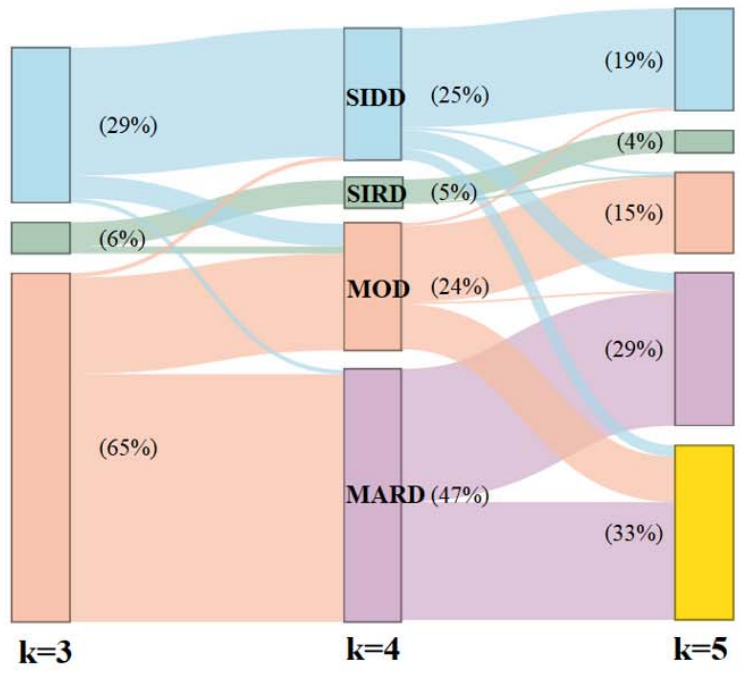

(A)

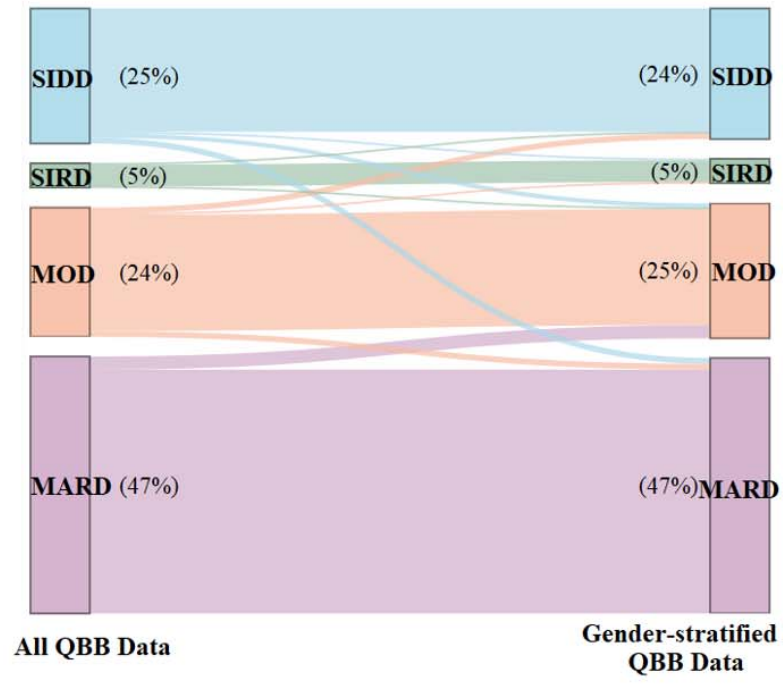

(B)

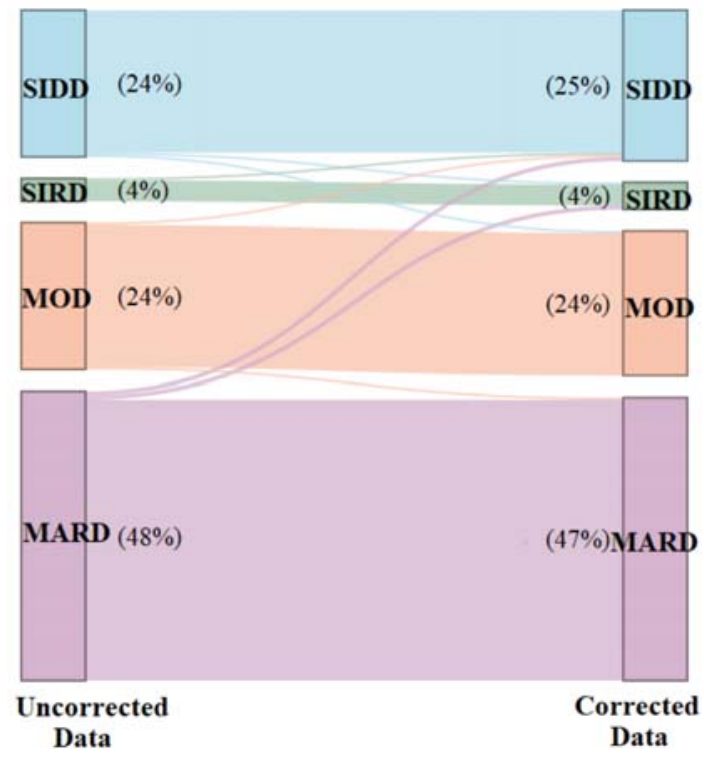

(C)

Supplementary Figure 4. Sankey diagrams showing changes in cluster assignment for various scenarios. A) The cluster assignments slightly changed when clustering QBB data using different $k(3,4$, and 5). To a large extent, clusters 1 and 2 kept the same cluster label using different $k$, while cluster 3 split into clusters 4 and 5 , at $k=4$ and $k=5$ respectively. B) Males and females were pooled, then clustered separately. Minor changes in the cluster assignments (7\%) 
medRxiv preprint doi: https://doi.org/10.1101/2022.01.13.22269204; this version posted January 13, 2022. The copyright holder for this preprint (which was not certified by peer review) is the author/funder, who has granted medRxiv a license to display the preprint in perpetuity.

All rights reserved. No reuse allowed without permission.

were observed when clustering the full data set compared to clustering the gender specific datasets. C) When clustering using uncorrected vs. corrected HOMA variables, most individuals retained the same cluster assignment using the fasting time - corrected data.
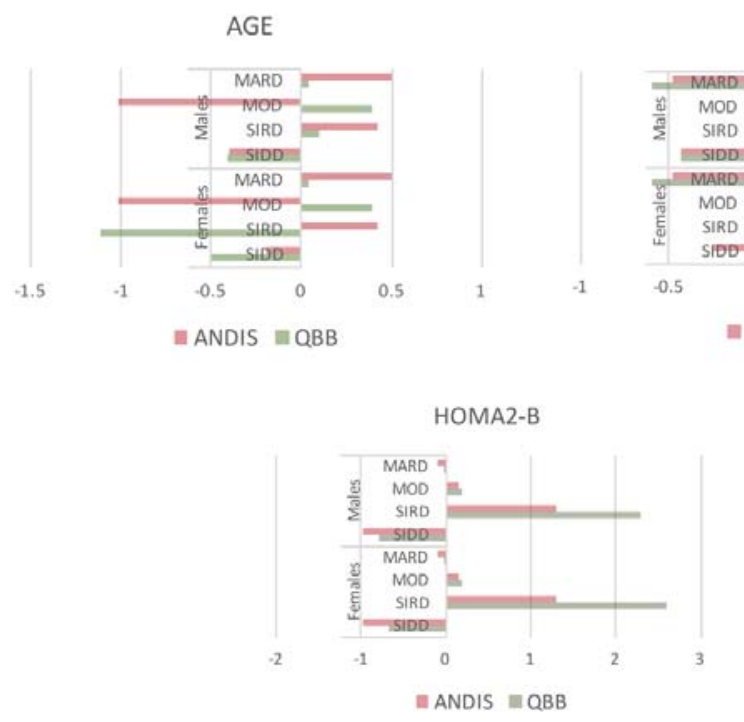
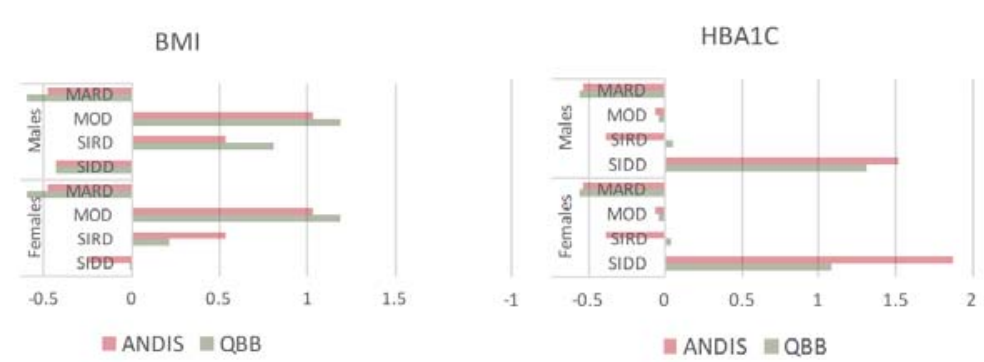

HOMA2-IR

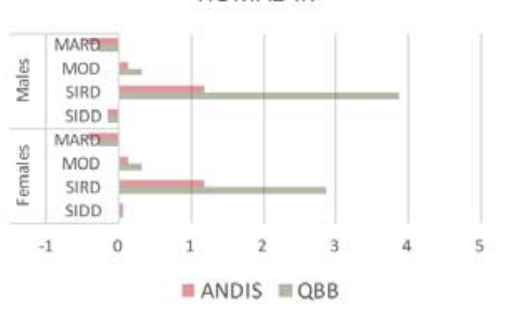

Supplementary Figure 5. Comparison of cluster coordinates for cluster allocations between QBB and ANDIS. Gender-specific variables including age, BMI, HbA 1 , HOMA2-B, and HOMA2-IR are shown for the SIDD, SIRD, MOD, and MARD diabetes subtypes. Differences between QBB and ANDIS were mainly observed in the age variable. 

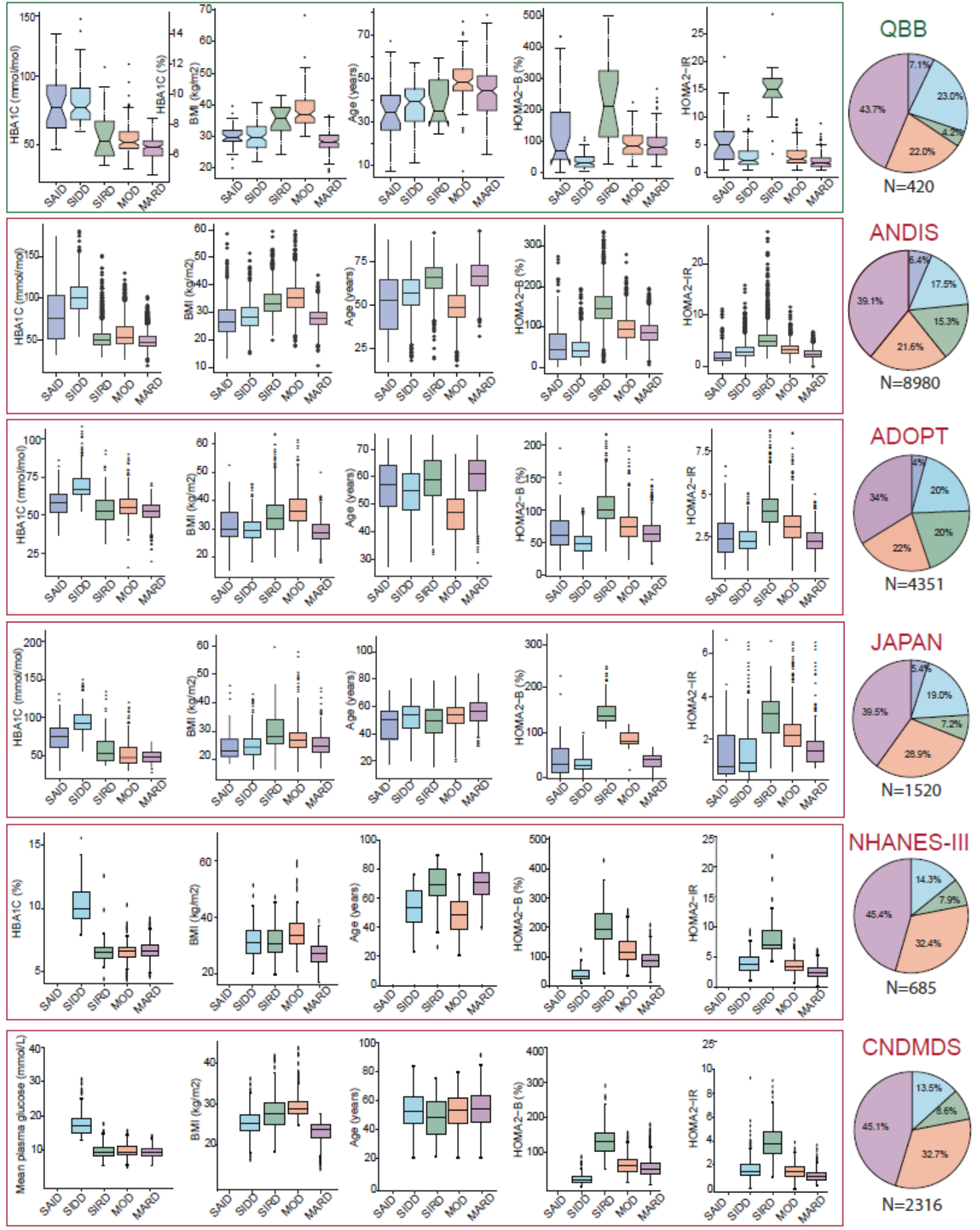

Supplementary Figure 6. Comparison of cluster variables across studies. The cluster variables were similar across many ethnicities (Arab, Scandinavian, British, Japanese, American, and Chinese). 
medRxiv preprint doi: https://doi.org/10.1101/2022.01.13.22269204; this version posted January 13, 2022. The copyright holder for this preprint (which was not certified by peer review) is the author/funder, who has granted medRxiv a license to display the preprint in perpetuity.

All rights reserved. No reuse allowed without permission.

[Figure provided as multi-page PDF file]

Supplementary Figure 7 and 8. Box plots for all protein and metabolite levels associated with a T2D specific cluster (see Figure 6 for an example). 


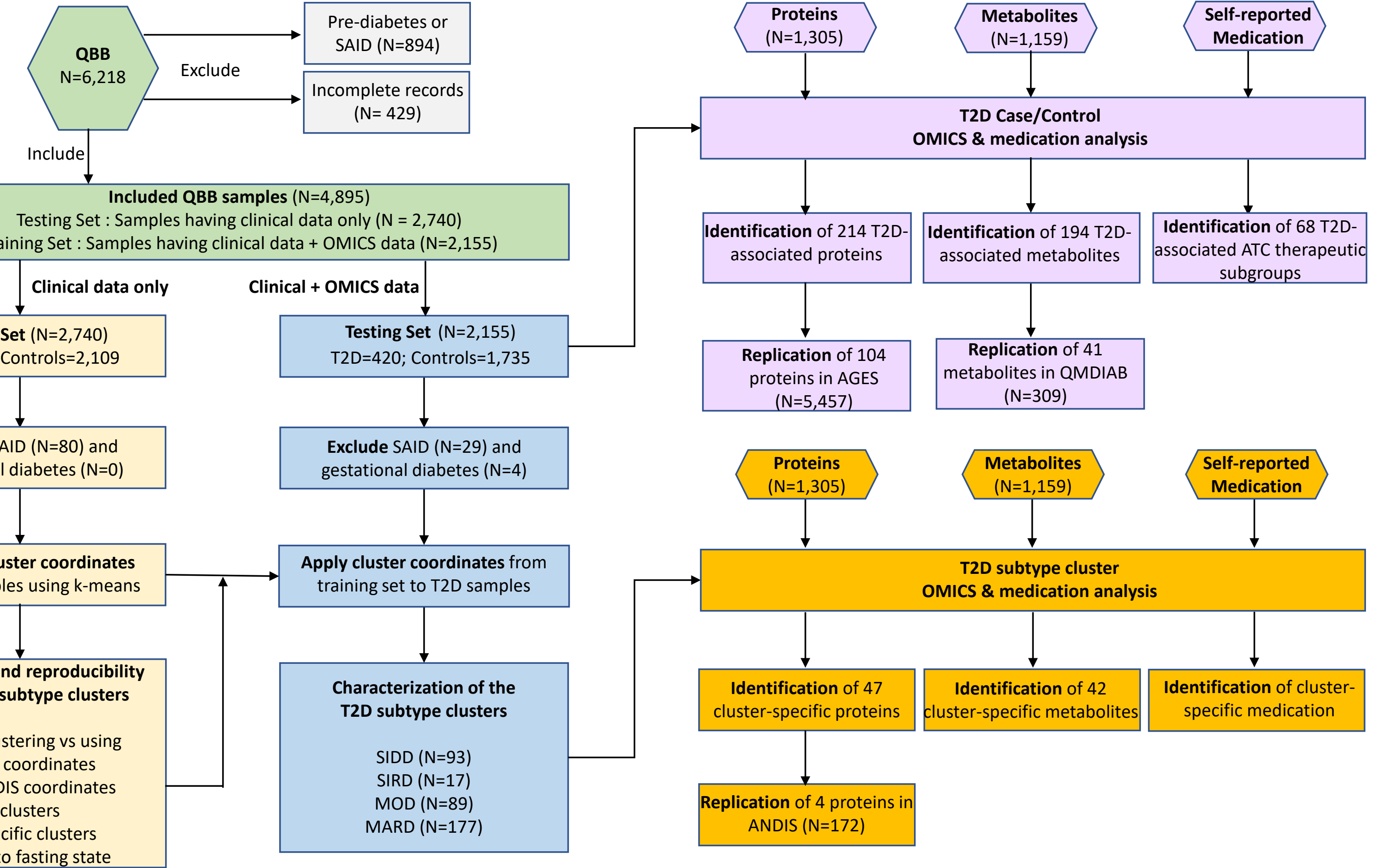




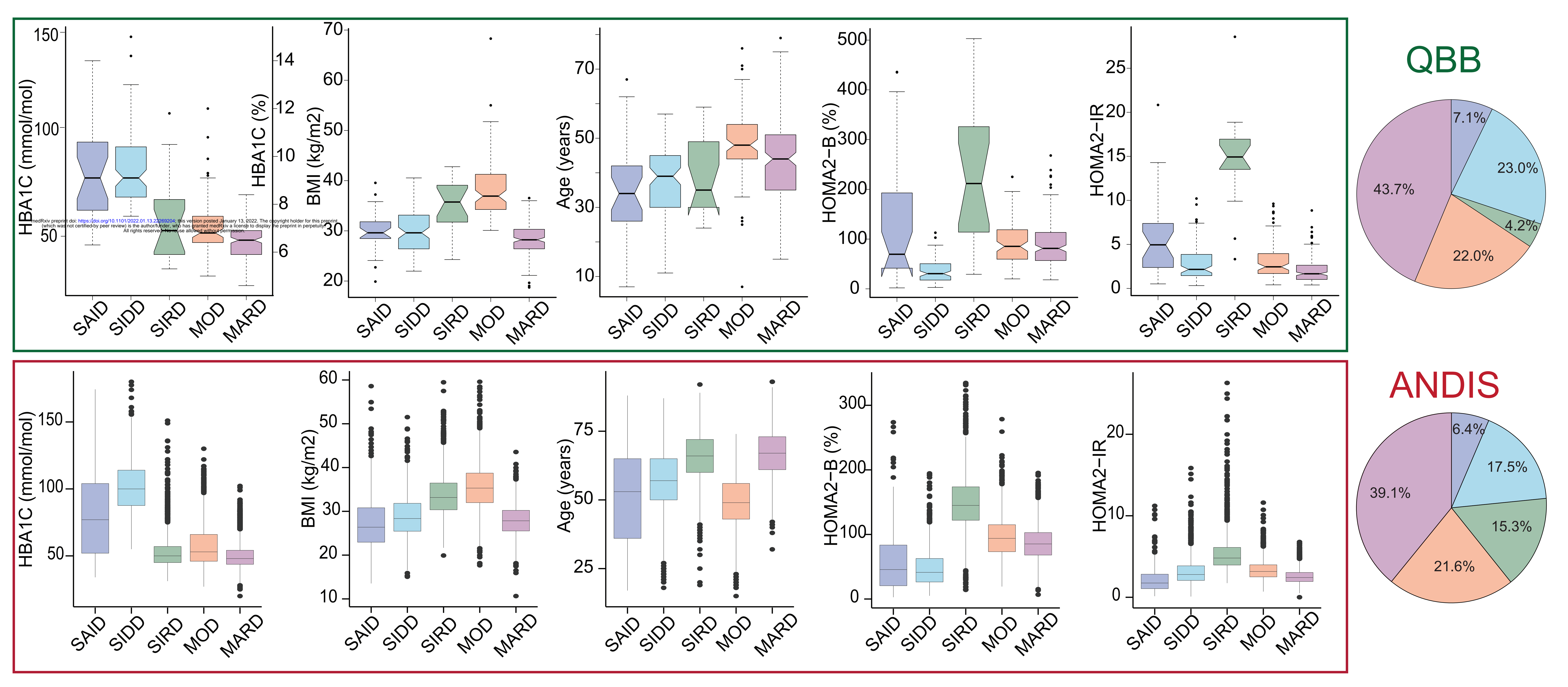




\section{SIRD (3\%)}

$(5 \%)$ STRD

MOD 245

Cinsters using training set ceuters
Clesters using lesting nol centers 


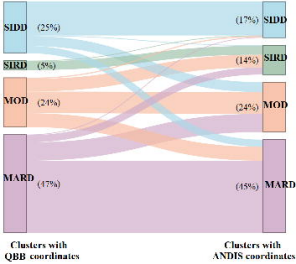




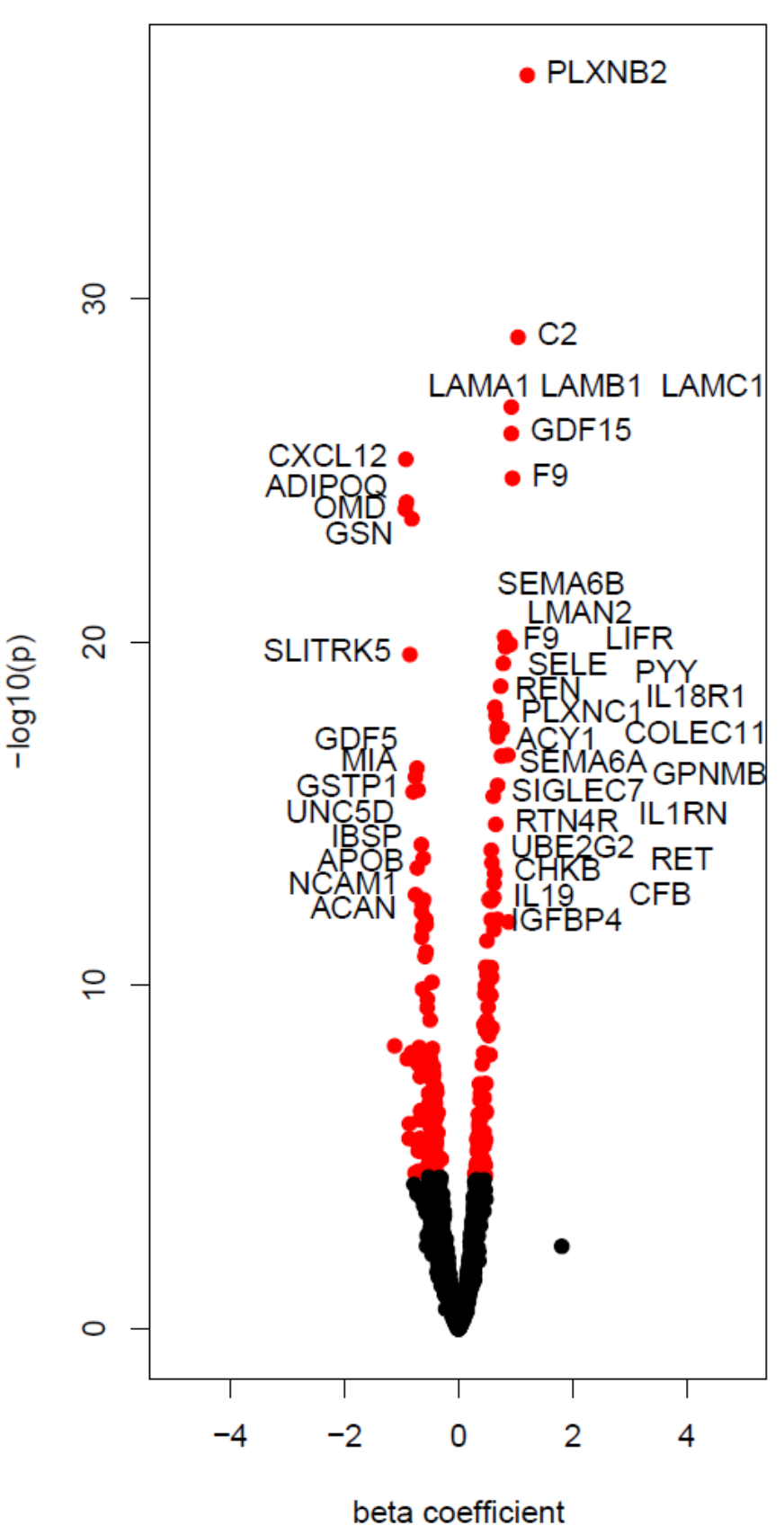

A
Common proteins

T2D protein + age + sex

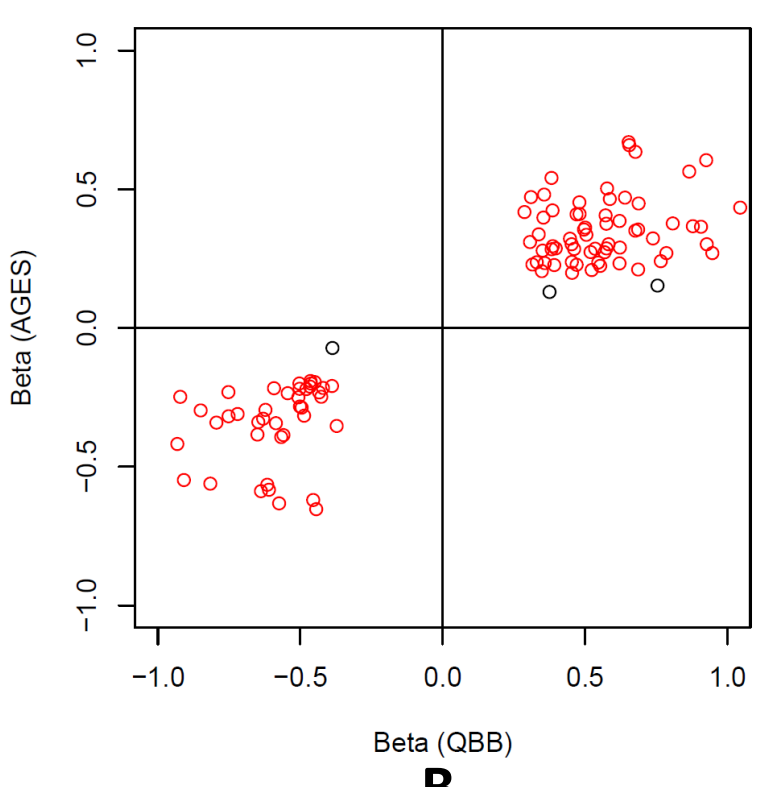

B

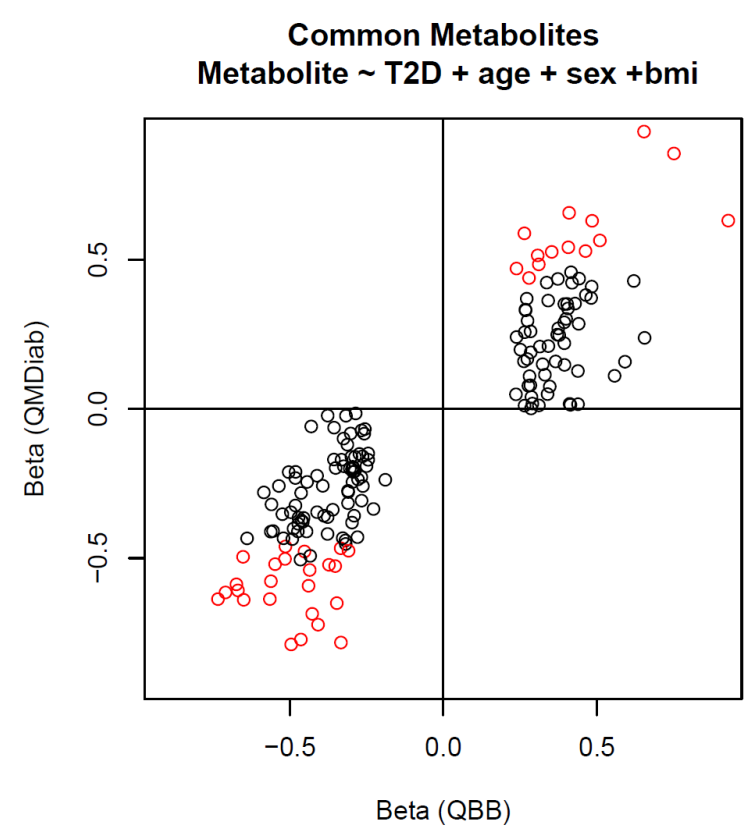

D

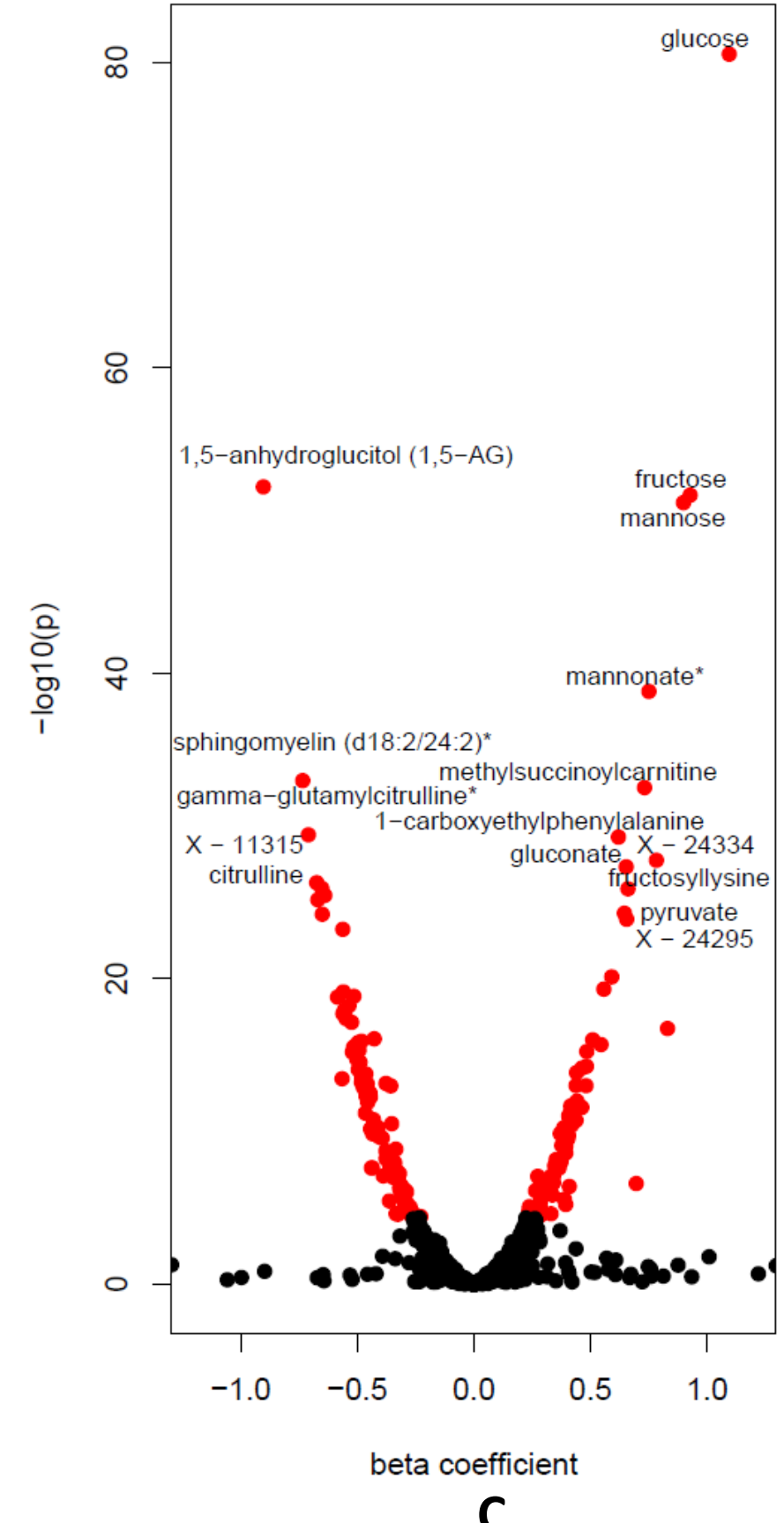

C 


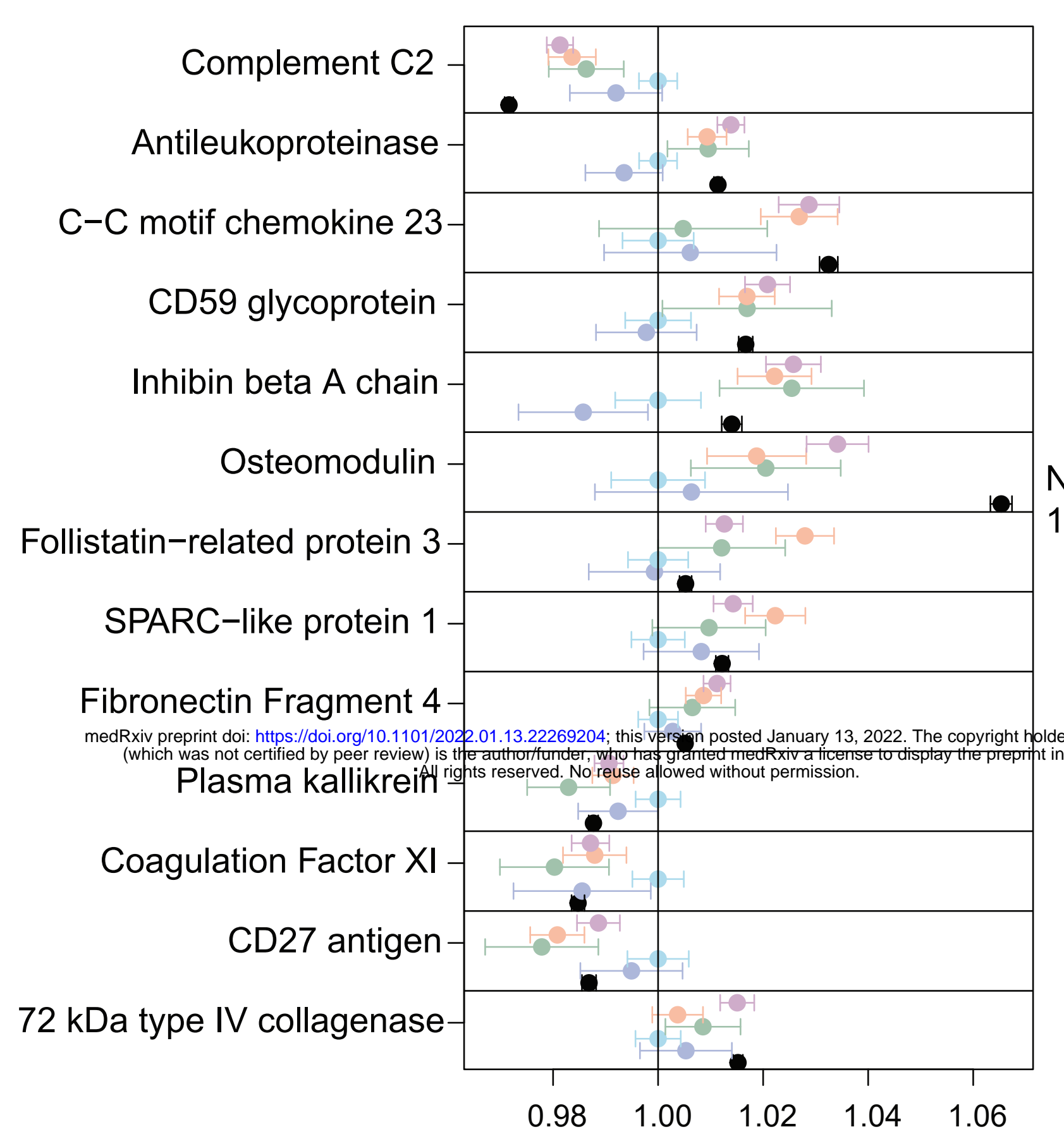

Relative concentration to SIDD cluster

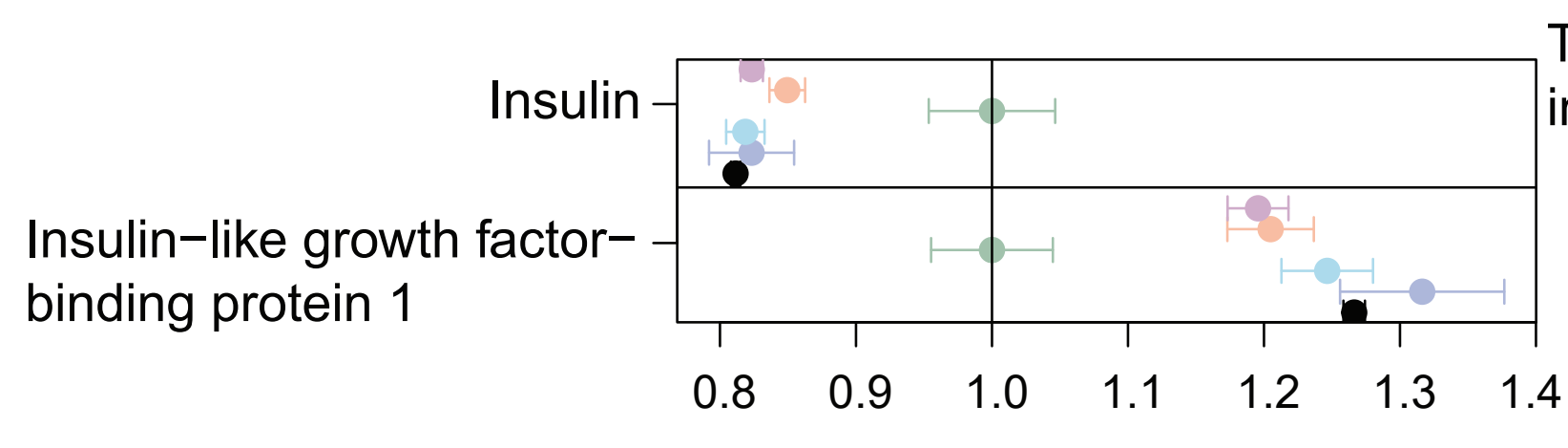

Relative concentration to SIRD cluster

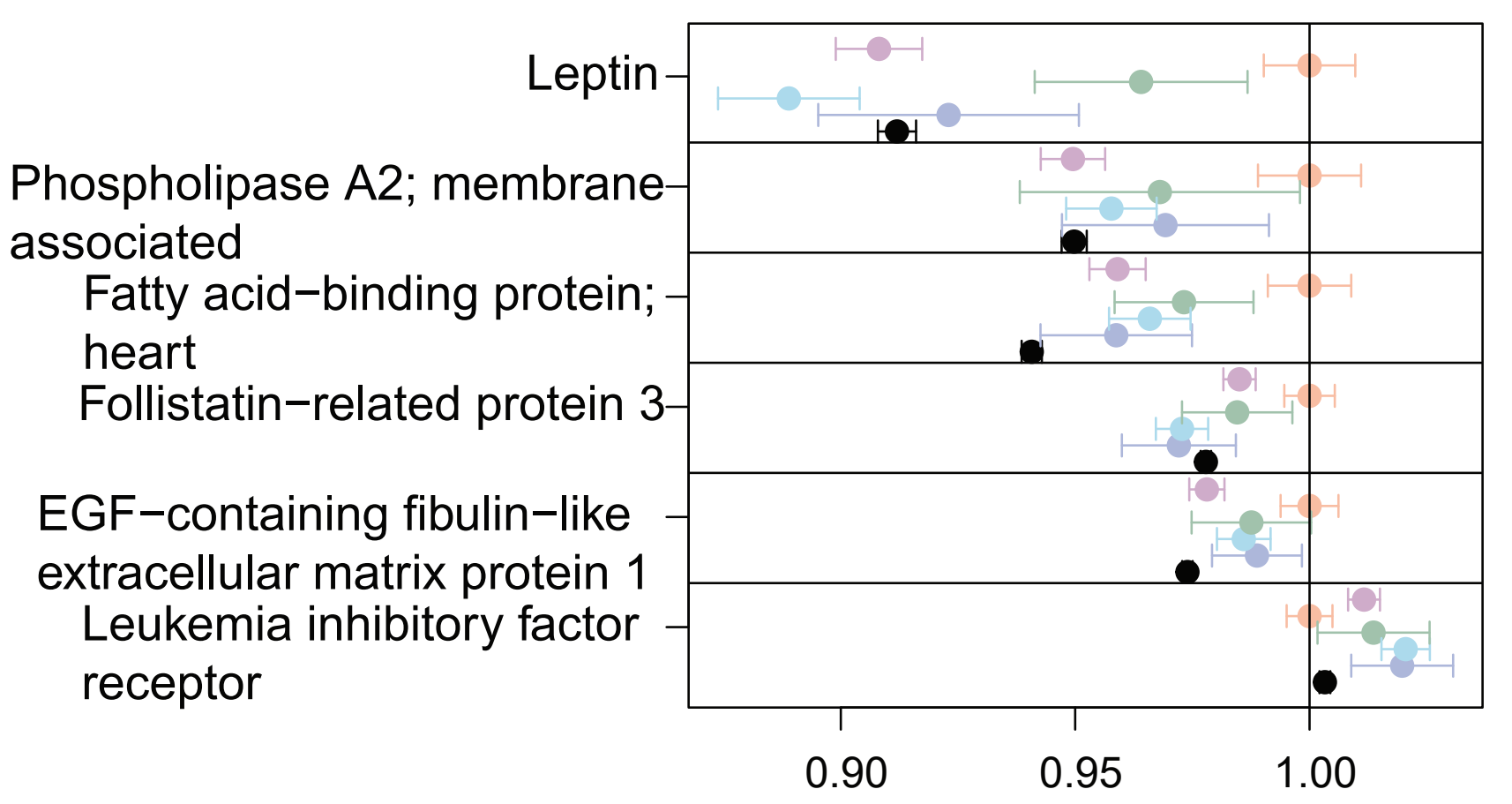

Relative concentration to MOD cluster

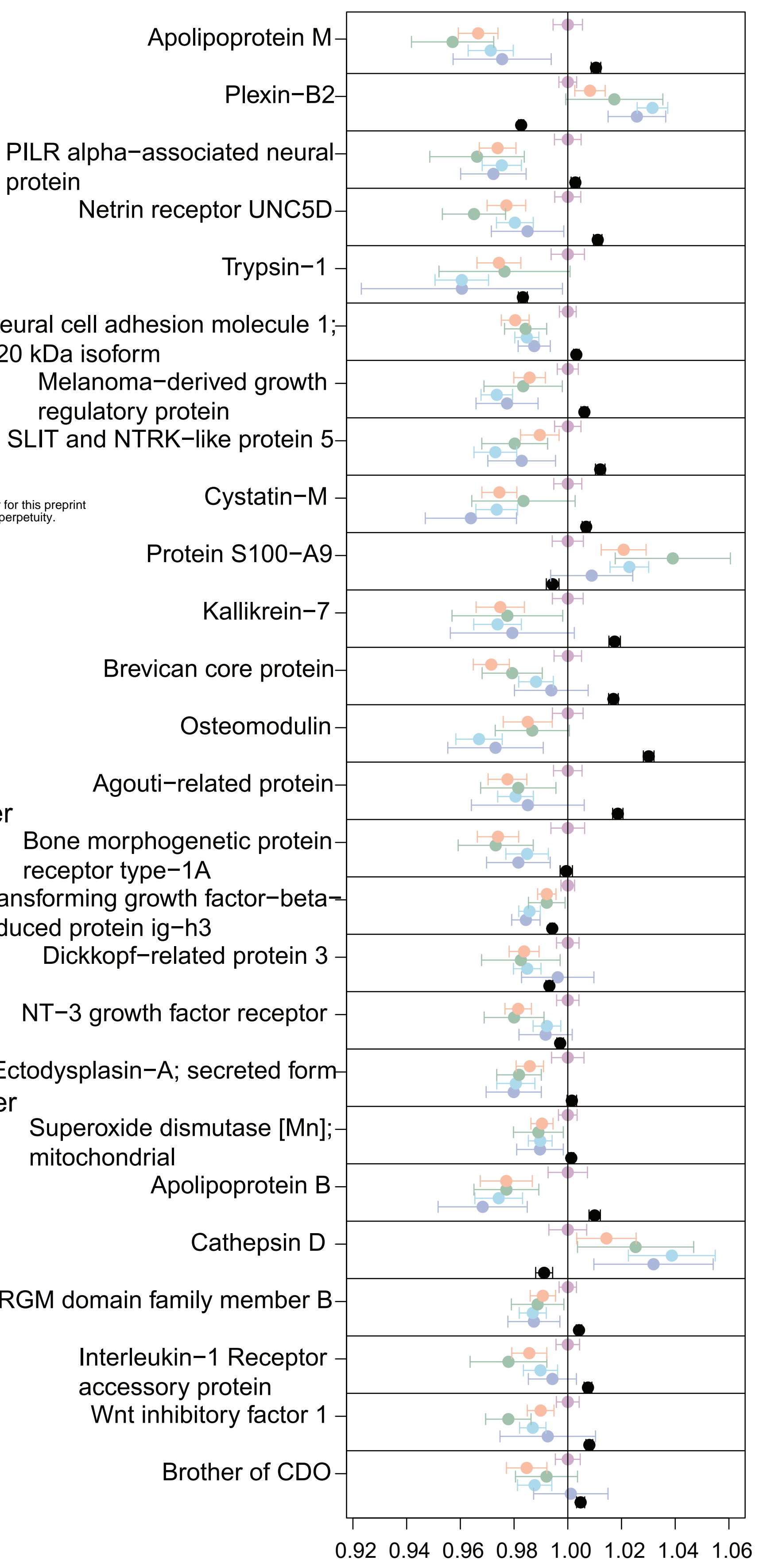

Relative concentration to MARD cluster 


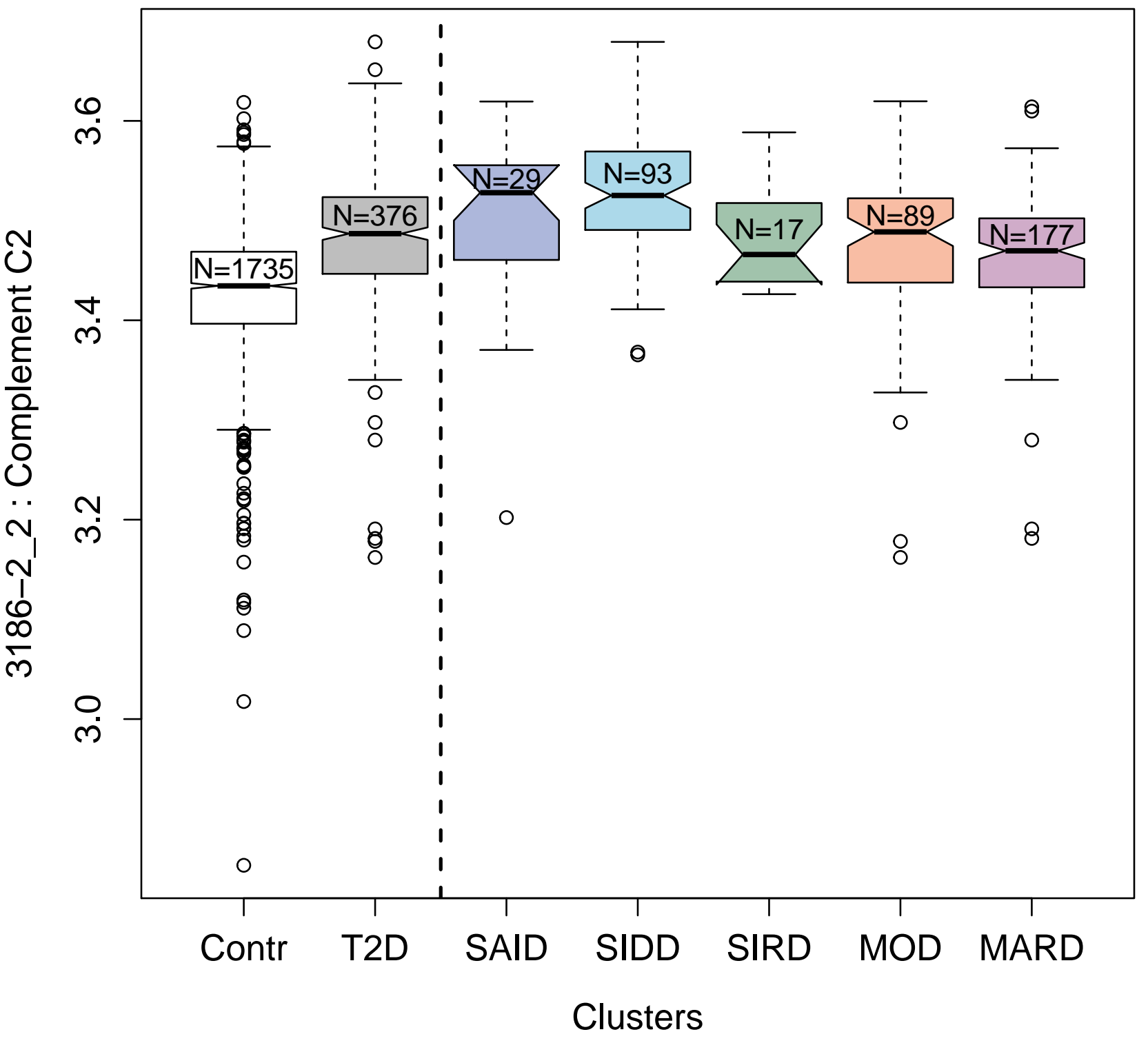




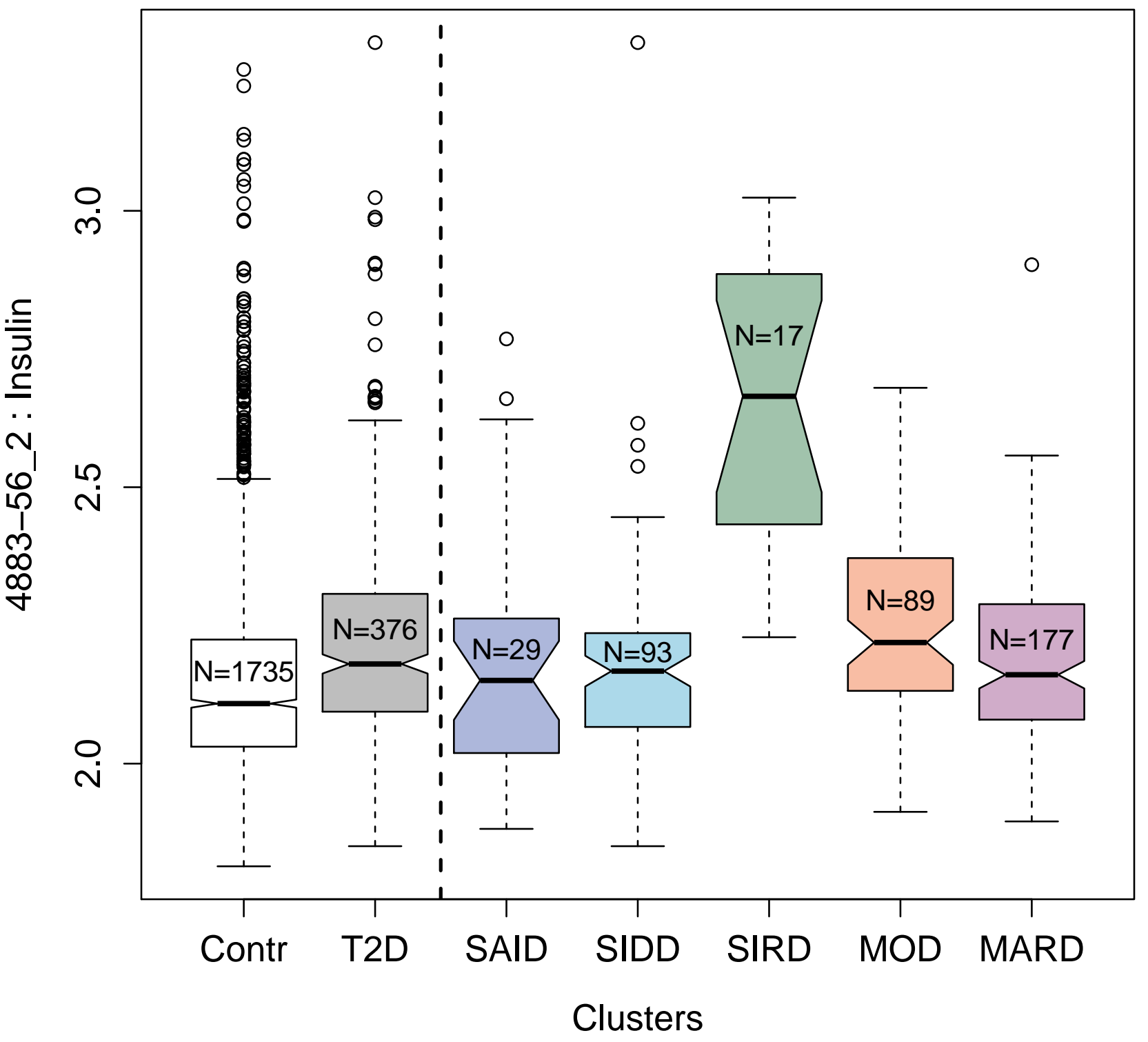




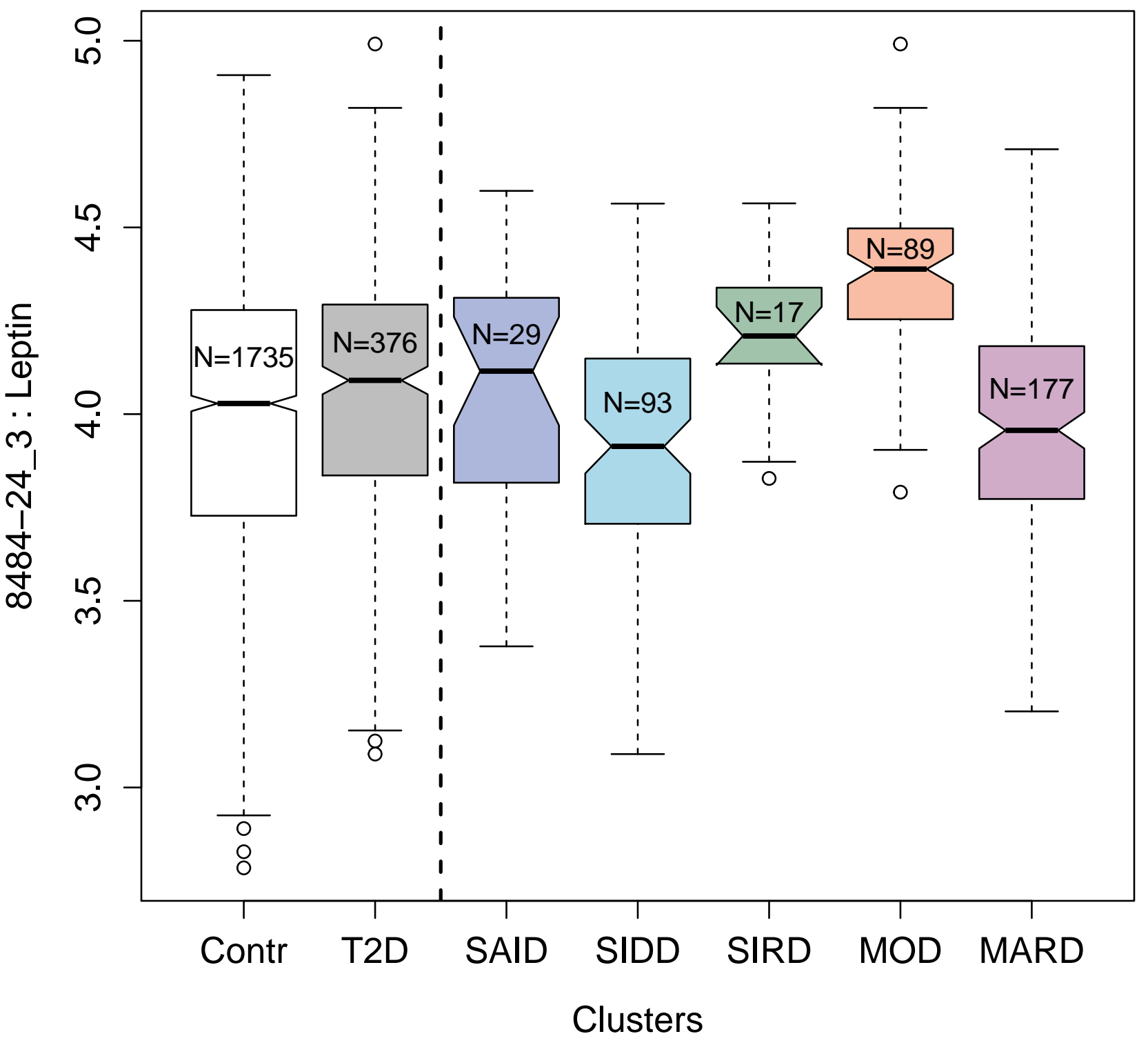




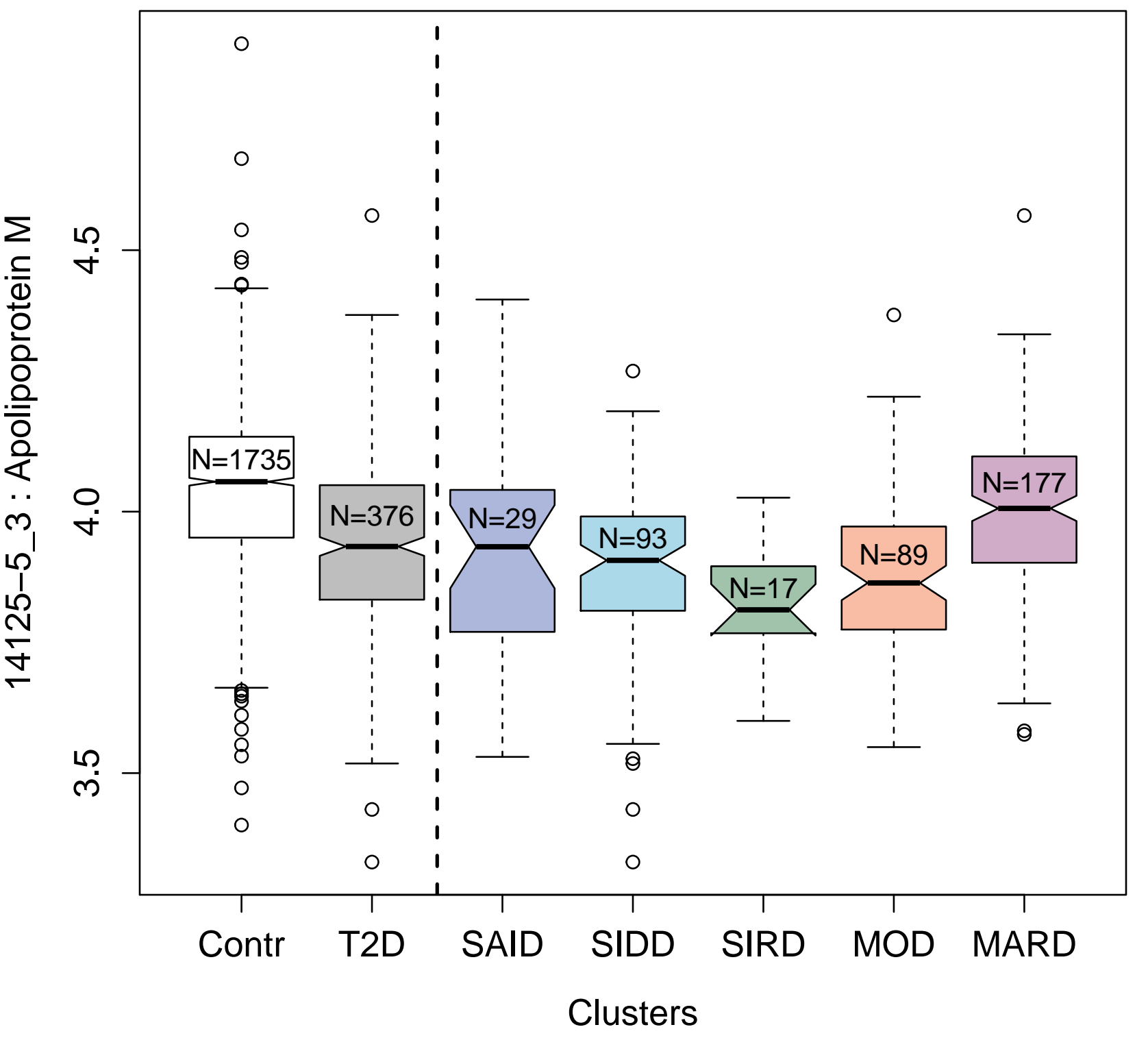




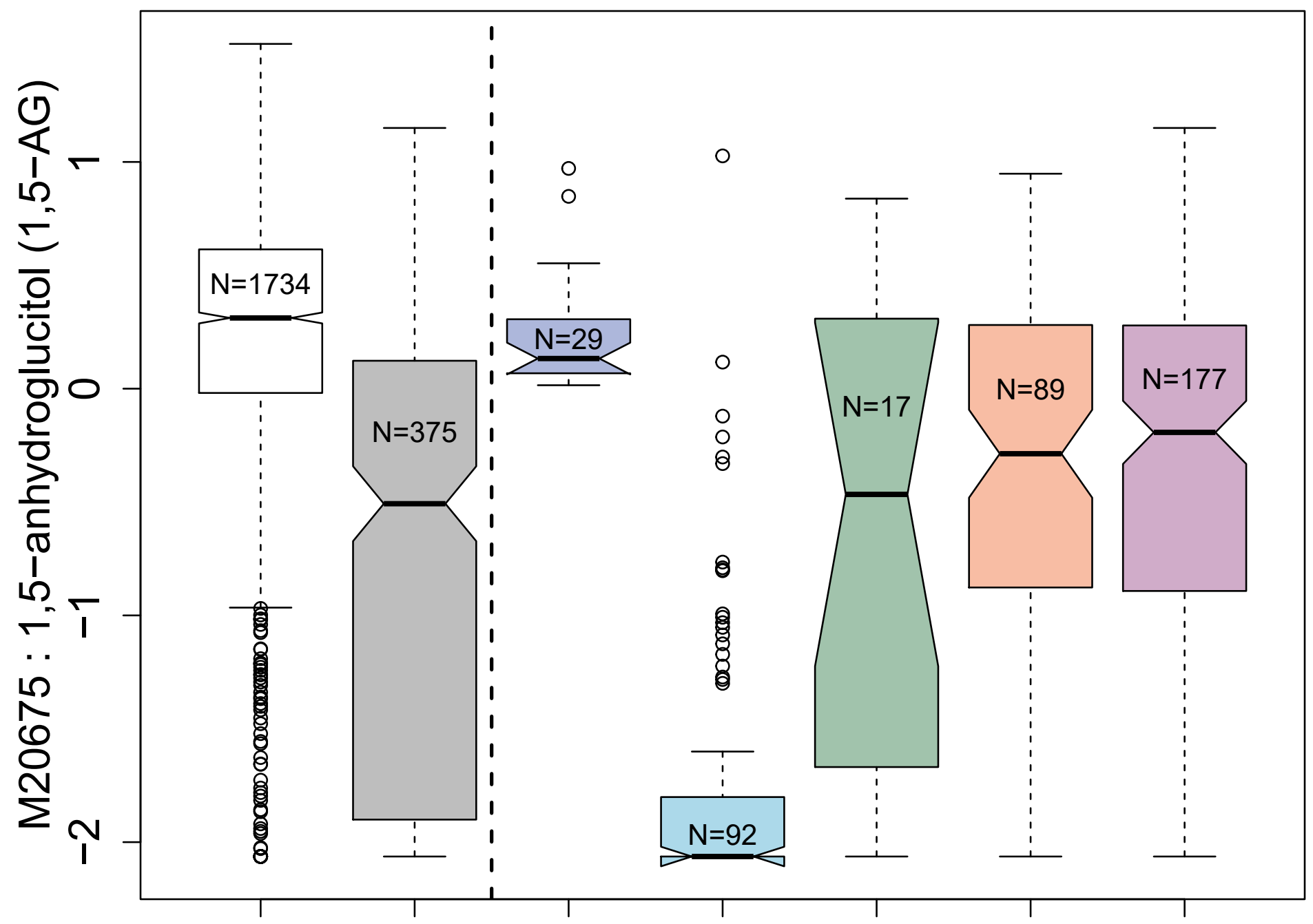

Contr T2D SAID SIDD SIRD MOD MARD Clusters 